\title{
Labor Unions, Globalization, and Mercantilism
}

\author{
Wolf-Heimo Grieben \\ Fuat Şener
}

\author{
CESIFO WORKING PAPER NO. 2889 \\ CATEgory 6: Fiscal Policy, Macroeconomics AND GrowTH \\ DECEMBER 2009
}

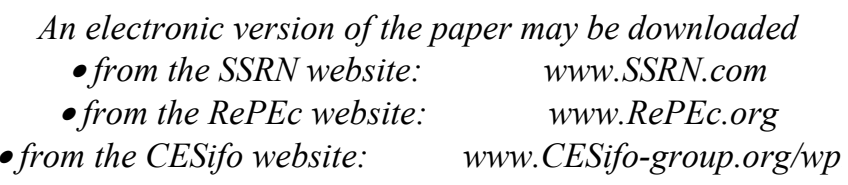




\title{
Labor Unions, Globalization, and Mercantilism
}

\begin{abstract}
We analyze the growth and welfare effects of globalization in a dynamic Schumpeterian North-South product-cycle model. Economic growth is driven by R\&D activities of Northern entrepreneurs. Top Northern production technologies are imitated by the South. In the North, there is wage bargaining between a labor union and firms, and a minimum wage rate exists. Unilateral Northern trade liberalization reduces the rate of innovation, increases Northern unemployment, and reduces both Northern and Southern per-capita welfare. The effects are reversed in the case of unilateral Southern trade liberalization. Hence, wage bargaining above a given minimum wage promotes mercantilist behavior of developed countries.
\end{abstract}

JEL-Code: F12, F43, J51, O31, O32.

Keywords: globalization, product cycle, endogenous growth, labor unions, minimum wage, mercantilism.

\author{
Wolf-Heimo Grieben \\ Department of Economics \\ University of Konstanz \\ 78457 Konstanz \\ Germany \\ heimo.grieben@uni-konstanz.de
}

\author{
Fuat Şener \\ Department of Economics \\ Union College \\ Schenectady \\ USA - New York, 12308 \\ senerm@union.edu
}

This version: 11 th December 2009

This is a significantly revised version of the paper "Labor Unions, Globalization and Endogenous Growth" that was presented at the May 2008 CESifo-Delphi conference on "Governments, Institutions and Macroeconomic Performance" in Munich. We thank the participants for helpful comments and discussion. Part of this work was done while WolfHeimo Grieben was a visiting scholar at the Economics Department of Columbia University, New York, and Stockholm School of Economics. We thank them for their hospitality. This work was supported by a grant from the Ministry of Science, Research and the Arts of BadenWürttemberg, Germany (Az: 21-655.042-5-2/1) to Wolf-Heimo Grieben. 


\section{Introduction}

The period since the 1980s has been marked by a significant surge in "globalization" as evidenced by the substantial increase in the trade to GDP ratios of many countries across the globe, most notably those of large developing countries (such as China and India). It is commonly held that the current wave of globalization has been driven by the massive declines in existing trade barriers and communication costs, along with opening up of some countries to trade and investment flows for the first time. ${ }^{1}$ During this recent wave of globalization, the labor unions' impact on the labor markets of developed countries has remained surprisingly robust and persistent, especially in Continental European countries. Although the unionization rates have shown a downward trend since the 1980s for most OECD countries, the coverage of collective bargaining has remained relatively stable around or above $70 \%$ for most Continental European Countries (Nickell 2003, pp. 21-22, Nickell et al. 2005, pp. 6-7). Notably, the coordination of union wage bargaining, which captures the extent to which the negotiating parties take into account the possible negative employment effects of the bargained wage rate, has decreased in most OECD countries (see Nickell 2003, p. 22, and Ortigueira 2008).

There is a vast theoretical trade literature that studies the impact of various aspects of globalization on labor markets with unions. ${ }^{2}$ Surprisingly, however, almost all of the papers in this literature use static models without incorporating economic growth and dynamic trade patterns. ${ }^{3}$ In the meanwhile, the literature on growth and labor unions has been confined to closed-economy settings (e.g., Lingens, 2003, and Palokangas 1996, 2004). Hence, the question of how trade liberalization affects growth, employment and welfare in a setting with a unionized labor market remains open to investigation.

In this paper we tackle with this question by constructing a dynamic North-South trade model with union wage bargaining and $R \& D$ driven Schumpeterian growth. We examine the impact of globalization

1 See Wacziarg and Welch (2008) for evidence on the integration of large and previously closed economies with the global economy. See Tang (2006, Figures 2 and 3) for evidence on the decline in transport and communication costs. See Grieben and Şener (2009, Table 1) for evidence on falling tariff rates across the globe. Rodrik (1994) provides evidence on a significant wave of unilateral trade liberalization of many developing countries since the early 1980 s.

2 This literature includes, but is not restricted to, Mezzetti and Dinopoulos (1991), Huizinga (1993), Driffill and van der Ploeg (1995), Zhao (1995, 1998, 2001), Naylor (1998, 1999), Skaksen and Sørensen (2001), Gaston (2002), Egger and Egger (2003), Skaksen (2004), Andersen (2005), Andersen and Skaksen (2007), Lommerud et al. (2009), and Eckel and Egger (2009).

3 The only paper we are aware of which analyzes the impact of a certain facet of globalization on the union effects on growth and employment is by Palokangas (2005). He uses a symmetric multi-country framework, where countries are connected by technology spillovers (but with no trade in goods). Palokangas studies the effects of globalization by considering an increase in cross-country technology spillovers. 
on bargained wages, employment, innovation, and long-run welfare, where the latter two are ignored by most of the existing macroeconomic literature on labor unions. ${ }^{4}$

In our model the world economy consists of a continuum of industries. Northern entrepreneurs participate in industry-specific $R \& D$ races to innovate higher quality products. Successful innovators manufacture their top quality products using Northern labor and become global monopolists. Over time, Northern technologies can be imitated in the South where production costs are lower. With each Southern imitation success, industry production shifts from the North to the South. Further Northern innovation moves the corresponding industry back to the North. Consequently, the North exports newly-invented goods, and the South exports imitated products ("product-cycle trade"). ${ }^{5}$ The governments in both regions impose advalorem tariffs on imported products. Trade is balanced in equilibrium. We remove the scale effects on innovation by introducing R\&D difficulty, the level of which is determined endogenously by the Rent Protection Activities (RPAs) of Northern producers. In the North, a centralized Northern labor union bargains with Northern firms over the wage rate of Northern production workers. ${ }^{6}$ The objective of the labor union is to maximize the expected excess wage income over a given minimum wage set by the government. ${ }^{7}$ The union will bargain for a wage rate that is higher than the competitive wage level and this leads to unemployment.

${ }^{4}$ More generally, an extensive body of literature has emerged investigating the globalization effects on labor markets, partly also using a dynamic growth framework. One focus in this literature has been on wage inequality and/or unemployment, and distinguishing the impact of globalization from that of various forms of biased technological change (Davis 1998b, Dinopoulos and Segerstrom 1999, Arnold 2002, Ethier 2005, Grieben 2005, Moore and Ranjan 2005, and Şener 2001, 2006). Other papers focus on whether the effects of labor market rigidities in one country spill over to other countries (Davis 1998a, Meckl 2006, Alessandria and Delacroix 2008, Helpman and Itskhoki 2009). The growth and employment consequences of changes in labor market institutions in twocountry models with Schumpeterian growth have been studied in Grieben (2004) and Şener (2006), while Grieben (2009) investigates the globalization effects in a North-South Schumpeterian growth model at various degrees of Northern labor market rigidities.

5 Different versions of product-cycle trade have recently been proposed: in Gustafsson and Segerstrom (2009), product cycles are one-way only from North to South, where manufacturing of imitated products never moves back to the North. In Şener and Zhao (2009), the Northern stage of production is skipped altogether for some products, such that Northern newly invented goods are immediately produced in the South only ("iPod cycle").

${ }^{6}$ This is the main distinguishing feature relative to the baseline setting of our companion paper Grieben and Şener (2009), where wage rates are determined competitively. In that paper, we considered two variations of the institutional set-up for RPAs and an extension with a low-tech Southern sector that does not have technological progress. We found that tariffs do not matter for steady-state innovation and growth ("tariff-neutrality" result) in all settings, except for the case with a Southern low-tech sector.

${ }^{7}$ Minimum wages "are applied in more than 90 per cent of ILO member states" (ILO 2008, p. 34) and are becoming a more prevalent feature of the labor markets in developed countries recently, where, according to ILO (2008, p. 36, Table 2), the average annual increase of minimum wages in real terms within the period $2001-2007$ was $3.8 \%$. It turns out that the existence of a positive minimum wage rate is crucial for our main results. 
In our comparative-static analysis, we concentrate on changes in three different globalization parameters: the Southern imitation rate, the relative size of the Southern population which captures the presence of the South in the world trade markets, and import tariffs. In addition, we investigate the effects of changes in three Northern labor market policy parameters: the union's bargaining power, the minimum wage rate, and employment-protection costs for Northern firms.

We find that an increased Southern presence in the world economy increases Northern innovation and thus worldwide growth, and decreases Northern unemployment. The same results are obtained for unilateral Southern trade liberalization. However, the opposite results (declining growth and rising unemployment) follow from increased Southern imitation and unilateral Northern trade liberalization. A higher union bargaining power, an increase in the minimum-wage rate, or an increase in employment-protection costs for Northern firms reduce Northern innovation and increase Northern unemployment.

Our welfare analysis implies that for any given Southern import tariff rate it is optimal for the Northern policy maker to choose the highest Northern import tariff rate feasible. Moreover, the benefits of Northern protectionism in terms of both Northern and Southern per-capita welfare are increasing in the level of Northern labor market rigidities. In the meanwhile, for any given Northern tariff rate, it is optimal for the Southern policy maker to choose the lowest Southern tariff rate feasible. Moreover, the benefits of Southern trade liberalization in terms of both Northern and Southern per-capita welfare are also increasing in the level of Northern labor market rigidities. We establish these results analytically for Northern welfare and numerically for Southern welfare. In a cooperative equilibrium aimed at maximizing global welfare, we find that the policy decisions remain the same: the North chooses the highest feasible tariff rate and the South chooses the lowest feasible tariff rate.

It follows that our model provides an explanation for the apparent mercantilism at the WTO negotiations of Northern developed countries (i.e., to favor trade liberalization of Southern trade partner countries, but to oppose own tariff reductions) with persistent labor market rigidities. We note that our arguments rely on the dynamic welfare gains implied by the resulting increase in the Northern steady-state innovation rate, a point which has been ignored in the static literature. Furthermore, our explanation does not hinge on a terms-of-trade effect, a mechanism that has been emphasized by Bagwell and Staiger (1999) but heavily criticized by Ethier $(2004,2007)$.

In our companion paper Grieben and Şener (2009) with perfectly flexible labor markets in both the North and South, we find that tariffs are neutral on Northern innovation and growth. In the current setting, where we allow for rigidities in the Northern labor market and keep the Southern labor market flexible, we find that higher Northern tariffs raise the innovation rate whereas higher Southern tariffs reduce it. Taken 
together, the results of these two papers uncover the role of labor market institutions in determining the long-term growth effects of unilateral trade liberalization in Schumpeterian models, which has been largely neglected in the existing literature. We should note however that both in Grieben and Şener (2009) and in this paper, bilateral trade liberalization raises long-run growth. Hence, this finding appears to be a robust outcome of these Schumpeterian settings.

The remainder of this paper is organized as follows. Section 2 presents our basic model, derives the steady-state equilibrium, analyzes its properties including welfare results, and provides a numerical simulation of our model. Section 3 compares our main results with related literature. Section 4 concludes.

\section{The Basic Model}

\subsection{Household Behavior}

The world economy consists of two countries, the North and the South, indexed by $i \in\{N, S\}$, respectively. Each country has a fixed number of identical households, normalized to one. Let $N_{0 i}$ denote the population size and also the labor force size of country $i$ at time zero. The number of household members in both countries grows at the common rate $n>0$; thus, the population size in country $i$ at time $t$ equals $N_{t i}$ $=N_{0 i} e^{n t}$.

The representative household maximizes the utility function

$$
F_{i}(t)=\int_{0}^{\infty} N_{0 i} e^{-(\rho-n) t} \log f_{i}(t) d t \quad \text { for } i=N, S,
$$

where $\rho>n$ is the subjective discount rate. The function $\log f_{i}(t)$ stands for the instantaneous logarithmic utility function of each household member and is given by

$$
\log f_{i}(t) \equiv \int_{0}^{1} \log \left[\sum_{j} \lambda^{j(\omega, t)} x_{i}(j, \omega, t)\right] d \omega \quad \text { for } i=N, S,
$$

where $\lambda>1$ is the size of each quality improvement, $j(\omega, t)$ is the number of successful innovations in industry $\omega \in[0,1]$ up to time $t$, and $x_{i}(j, \omega, t)$ is the per-capita demand for a product of quality $j$ in industry $\omega$ at time $t$. Hence, as in the standard quality-ladder models, product quality starts at $\lambda^{0}=1$ in any industry $\omega$ and improves at discrete steps with each successful innovation, which is governed by a stochastic process.

The household optimization process consists of two steps. The first step is to allocate consumption expenditure across products to maximize $f_{i}(t)$ for given product prices. Since products in a typical industry $\omega$ differ only in their quality, and $\lambda$ units of quality $j$ are a perfect substitute for one unit of quality $j+1$, 
households purchase in each industry only the product with the lowest quality-adjusted price. In addition, since products enter (2) symmetrically, each household spreads its consumption expenditure evenly across product lines. It thus follows that per-capita demand for each industry's product is $x_{i}(\omega, t)=c_{i}(t) / p(t)$ where $c_{i}$ is per-capita consumption expenditure in country $i$, and $p(t)$ is the price of the purchased good.

Given the static demand functions, the second step is to determine the consumption expenditure path over time. This involves maximizing

$$
\int_{0}^{\infty} N_{0 i} e^{-(\rho-n) t} \log c_{i}(t) d t \quad \text { for } i=N, S
$$

subject to the intertemporal budget constraint

$$
F \dot{A}_{i}(t)=W I_{i}(t)+r(t) F A_{i}(t)-c_{i}(t) N_{i}(t)
$$

where $F A_{i}(t)$ denotes the stock of financial assets owned by the household, $W I_{i}(t)$ is the household's expected wage income and $r(t)$ is the instantaneous rate of return in the global market. The expected wage component $W I_{i}(t)$ accounts for unemployment which will arise for Northern workers. The solution to this dynamic optimization problem gives the familiar Euler equation ("Keynes-Ramsey rule")

$$
\frac{\dot{c}_{i}(t)}{c_{i}(t)}=r(t)-\rho \quad \text { for } i=N, S .
$$

At the steady-state equilibrium, $c_{i}$ will be constant; thus $r(t)=\rho$. Since we focus on steady-states and consider structurally-identical industries, we henceforth drop the time index $t$ and the industry index $\omega$.

\subsection{Labor and Activities}

Labor is the only factor of production and is immobile across countries. In the North, the labor force consists of specialized and general-purpose workers, with the fixed proportion of the former given as $s_{N} \in(0$, 1) and that of the latter given as $1-S_{N}$. In the North, there are three types of activities: innovation, manufacturing of final goods, and rent protection. General-purpose workers can be employed in innovation or goods production, whereas specialized workers (lawyers, lobbyists) are only employed in Rent Protection Activities (RPAs), the activities that are undertaken by incumbent firms to deter the innovation efforts targeted at their products. ${ }^{8}$ In the South, there is only one type of labor used in manufacturing of final

8 RPAs are first introduced in a closed economy endogenous growth setting by Dinopoulos and Syropoulos (2007). Grieben and Şener (2009) discuss the empirical evidence on RPAs in a North-South context. Our labor assignment follows Dinopoulos and Syropoulos (2007) and Grieben and Şener (2009). As is discussed in the latter paper, its advantage is that it yields fully-endogenous growth (in the sense that the steady-state growth rate depends on all 
goods which is the only type of activity (Appendix R.1, which is available upon request, extends the model for endogenous imitation of Northern state-of-the-art products as a second type of activity of Southern labor).

\subsection{Product Markets}

The world economy consists of a continuum of structurally-identical industries indexed by $\omega \in[0,1]$. In each industry, Northern entrepreneurs participate in $R \& D$ races to discover the technology of producing next-generation products, whose quality is $\lambda>1$ times higher than the current-generation product. Whenever a higher quality product is discovered in the North, a new R\&D race starts and the technology of producing the previous-generation product becomes common knowledge to all firms in the global economy. In the global product markets, firms engage in Bertrand price competition to offer the lowest qualityadjusted price given their state of technology and regional labor costs. In the North, workers are represented by a labor union and wages are determined by decentralized wage bargaining. In the South, competitive labor market conditions apply. We normalize the Southern wage rate to 1 and denote the Northern wage rate of general-purpose labor as $\left.w_{L} \in\right] 1, \lambda[$. In both countries, production of one unit of final goods requires one unit of general-purpose labor, regardless of the quality level of the manufactured goods. The governments of both regions impose ad-valorem tariffs on imported goods. We denote by $\tau_{N} \geq 0$ the tariff rate imposed by the North and by $\tau_{S} \geq 0$ the tariff rate imposed by the South.

For each industry, there are two possible structures at any point in time. Whenever a Northern entrepreneur discovers a next-generation product, the resulting structure is a Northern industry, in which the Northern quality leader competes with Southern followers who have access to the previous-generation technology. Whenever the technology of producing a current-generation product leaks to the South, all Southern firms gain access to the current-generation technology. The resulting structure is a Southern industry, in which the Northern quality leader competes with Southern followers. ${ }^{9}$

Consider first the profits of firms in a Northern industry. In the Northern market, the Southern followers face an ad-valorem tariff rate $\tau_{N}$. By pricing at marginal cost and accounting for the Northern tariff rate, the followers can offer their goods to Northern consumers at a price $1+\tau_{N}$. In this case, the Northern

parameters of the model) with a parsimonious structure by creating a link between the innovation rate and the Northern wage rate for specialized relative to general-purpose workers in the simplest possible way.

${ }^{9}$ Northern followers' unit cost is $w_{L}$ whereas the Southern followers' unit cost is 1 . Northern followers cannot compete with Southern followers in the Southern market if $w_{L}\left(1+\tau_{N}\right)>1$. This condition holds automatically given that $w_{L}>1$ at the steady-state. Moreover, Northern followers cannot compete with Southern followers in the Northern market provided $w_{L}>1+\tau_{N}$, which we impose. 
quality leader charges the limit price $p_{N}^{N}=\lambda\left(1+\tau_{N}\right)-\varepsilon$ with $\varepsilon \rightarrow 0$ and drives the Southern followers out of the market. The profits of the Northern quality leader from sales in the Northern market are:

$$
\pi_{N}^{N}=\frac{c_{N} N_{N}}{\lambda\left(1+\tau_{N}\right)}\left[\lambda\left(1+\tau_{N}\right)-w_{L}\right]=c_{N} N_{N}\left[1-\frac{w_{L}}{\lambda\left(1+\tau_{N}\right)}\right] .
$$

In the Southern market, the Northern quality leader faces an ad-valorem tariff rate $\tau_{S}$. Under marginal cost pricing, the Southern followers can offer a price of 1 . To capture the Southern market, the Northern quality leader must set its price such that the price faced by the Southern consumers does not exceed $\lambda$. This implies that the Northern leader charges the limit price $p_{N}^{S}=\lambda-\varepsilon$ with $\varepsilon \rightarrow 0$, of which the Northern firm receives only $\lambda /\left(1+\tau_{S}\right) .{ }^{10}$ The profits of the Northern quality leader from sales in the Southern market are:

$$
\pi_{N}^{S}=\frac{c_{S} N_{S}}{\lambda}\left(\frac{\lambda}{1+\tau_{S}}-w_{L}\right)
$$

For $\pi_{N}^{S}>0$, we need $\tau_{S}<\left(\lambda / w_{L}\right)-1$, which we maintain. Hence total profits from sales of Northern monopolists are:

$$
\pi_{N}^{P}=\pi_{N}^{N}+\pi_{N}^{S}=c_{N} N_{N}\left[1-\frac{w_{L}}{\lambda\left(1+\tau_{N}\right)}\right]+c_{S} N_{S}\left(\frac{1}{1+\tau_{S}}-\frac{w_{L}}{\lambda}\right) .
$$

Consider now the profits of firms in a Southern industry. In the Southern market, the Southern followers can charge $p_{S}^{S}=1$ and price out the Northern quality leader who can offer a price of $w_{L}\left(1+\tau_{S}\right)>1$ by charging at marginal cost. In the Northern market, the Southern followers can offer an after-tariff product price of $p_{S}^{N}=1+\tau_{N}$. Under the restriction that $w_{L}>1+\tau_{N}$, which we maintain, the Northern quality leader who can offer its product at $w_{L}$ is again priced out. Consequently, in Southern industries only Southern firms prevail by charging marginal cost and they earn zero profits. Hence, in Southern industries, Bertrand pricing with many firms effectively replicates the perfectly competitive outcome. ${ }^{11}$

\footnotetext{
${ }^{10}$ It immediately follows that Northern quality leaders cannot benefit from export taxes: for any export price exceeding $\lambda$, Southern consumers would switch to local goods although these are of inferior quality. This implication will be important when we later argue that this model is able to explain actual mercantilist behavior of Northern countries at WTO trade rounds, which includes the observation that export taxes are not used to improve terms of trade.

${ }^{11}$ This is in accord with the modeling in, e.g., Glass (2004), Sayek and Şener (2006), and Şener and Zhao (2009). As is well known from standard textbooks in trade theory, the Southern government has no incentive to offer export subsidies to its competitive exporting industries, given that WTO rules allow the Northern government to react by
} 
While Northern quality leaders earn monopoly profits, they simultaneously expend resources for RPAs, i.e. to safeguard their monopoly positions against their Northern rivals (e.g., by investing in trade secrecy, patent enforcement through litigation, lobbying the government to influence intellectual property legislation and etc.). For this purpose, each Northern incumbent hires Northern specialized labor at a wage rate of $w_{H}$. The cost of performing $X(t)$ units of RPAs is $w_{H} \gamma X$, where $\gamma$ is the unit labor requirement of such activities. Hence, a Northern incumbent's profit flow net of rent protection costs then equals:

$$
\pi_{N}=\pi_{N}^{P}-w_{H} \gamma X
$$

\subsection{Technology of Innovation and Optimal Innovation Decision}

In the North, there are sequential and stochastic R\&D races in each industry $\omega \in[0,1]$ to discover the next-generation product. The R\&D technology is identical across Northern firms. The instantaneous probability of innovation success (the Poisson arrival rate) by firm $j$ is given as

$$
\iota_{j}=I_{j} / D \quad \text { with } \quad \dot{D}=n_{N} \delta X
$$

where $I_{j}$ represents the innovation intensity of a typical Northern entrepreneur $j$ targeting industry $\omega$, and $D$ measures the difficulty of conducting R\&D in industry $\omega$ at time $t$. According to (8), R\&D difficulty $D$ is modeled as a stock variable, where $n_{N}$ is the proportion of industries located in the North, $X$ is the flow of RPAs undertaken by the Northern incumbent in industry $\omega$ at time $t$, and $\delta$ measures the effectiveness of these RPAs. The equation of motion for $D$ in (8) implies that whenever an industry is registered as a Northern industry - the probability of which is equal to $n_{N}$ in equilibrium - Northern incumbents undertake RPAs which increase the stock of R\&D difficulty in that industry by $\delta X$. For a constant steady-state innovation rate, R\&D difficulty must grow at the same rate as the labor force, hence $\dot{D}=n D$ is required. From this and (8), we obtain the steady-state stock of R\&D difficulty:

$$
D=n_{N} \delta X / n
$$

Since innovation success is independently distributed across firms and industries, the Poisson arrival rate for innovation at the industry level (which is 'the' Northern innovation rate) equals

$$
\iota=\sum_{j} l_{j}=I / D \quad \text { with } \quad I=\sum_{j} I_{j}
$$

imposing countervailing duties, thereby effectively collecting the Southern export subsidies while leaving consumers and producers in both countries unaffected. Again, this implication will be important when we later use this model to explain actual mercantilist behavior of Northern countries at WTO trade rounds, which includes the observation that countervailing-duty laws exist. 
Entrepreneurs participating in R\&D races hire general-purpose labor to perform R\&D. The cost of conducting $I_{j}$ units of R\&D activity is $w_{L}\left(1-\sigma_{l}\right) a_{l} I_{j}$, where $\sigma_{l}$ is a public R\&D subsidy rate (financed by lump-sum taxation for simplicity), and $a_{l}$ is the unit labor requirement of R\&D. Imposing the usual freeentry assumption for $R \& D$ races, expected profits from $R \& D$ are competed away, and the maximization problem

$$
\max _{R_{j}} \frac{v_{N} I_{j}}{D} d t-w_{L}\left(1-\sigma_{\imath}\right) a_{l} I_{j} d t
$$

yields

$$
v_{N}=w_{L}\left(1-\sigma_{\imath}\right) a_{\imath} D
$$

where $v_{N}$ is the firm value of a successful Northern innovator.

\subsection{The Stock Market}

The savings of consumers are channeled to firms investing in R\&D by means of a global stock market. Over a small time period $d t$, the stockholders of a Northern quality leader operating in a Northern industry receive dividend payments $\pi_{N} d t$. With probability $(l+\mu) d t$, successful innovation or imitation takes place and the Northern firm is driven out of the market. The stockholders face the risk of a complete capital loss of size $v_{N}$. When shutting down, the firm has to pay liquidation costs proportional to its valuation $B v_{N}$, where $0<B<1$. With probability $1-(l+\mu) d t$, neither Northern innovation nor Southern imitation takes place, and the firm experiences a capital gain $\dot{v}_{N} d t$. Consumers can engage in complete diversification of their asset portfolio to eliminate the industry-specific risk of unsuccessful R\&D efforts, hence in an arbitrage-free asset market equilibrium, the expected return from a stock issued by the Northern firm must equal the return of a risk-free asset that pays the market interest rate on an investment of equal size during the same time period:

$$
\pi_{N} d t-v_{N}(1+B)(t+\mu) d t+\dot{v}_{N}[1-(t+\mu) d t] d t=r v_{N} d t
$$

Solving (12) for $v_{N}$ and imposing $d t \rightarrow 0$ yields

$$
v_{N}=\frac{\pi_{N}}{r+(1+B)(l+\mu)-\left(\dot{v}_{N} / v_{N}\right)}
$$

as the appropriately discounted monopoly profits determining the value of an incumbent firm. 


\subsection{Optimal Rent Protection Decision by Northern Incumbents}

Substituting $D$ from (9) into (10), we derive $\imath(X)=\operatorname{In} / n_{N} \delta X$, which clearly shows that an increase in RPAs $X$ diminishes the threat of replacement faced by the incumbent as it reduces $t$. The incumbent avoids the capital loss $v_{N}$ and realizes the change in its valuation $\dot{v}_{N}$ by the extent of the decline in $\imath$ per unit of time. In the meanwhile each unit of RPA costs $w_{H} \gamma$ per unit of time. When choosing the optimal level of $X$, the Northern incumbent weighs the marginal gains against the marginal costs. Formally, the firm chooses $X$ to maximize the expected returns on its stocks

$$
\left(\pi_{N}^{P}-w_{H} \gamma X\right) d t-v_{N}(1+B)[\imath(X)+\mu(X)] d t+\dot{v}_{N} d t\{1-[\imath(X)+\mu(X)] d t\},
$$

where (7) is used for $\pi_{N}$ and the expression for $\imath(X)$ is from above. Setting the derivative of the expected return with respect to $X$ to zero, using $d \imath(X) / d X=-\imath / X<0$, and taking limits as $d t \rightarrow 0$, we derive the first order condition for the optimal $X$ as:

$$
X=\imath v_{N}(1+B) /\left(w_{H} \gamma\right)
$$

Intuitively, the optimal level of RPAs $X$ increases with the firm value $v_{N}$ (since there is more at stake) and the replacement rate due to innovation $\imath$ (the instantaneous probability of full capital loss at each point in time), and it decreases with the unit cost of RPAs $w_{H} \gamma$. Finally, $X$ increases with liquidation costs $B$, hence equation (14) formalizes the notion that the presence of liquidation costs encourages incumbents to make an extra effort to prolong their monopoly power by raising the level of RPAs.

Using (14) together with (7) and (6) in (13) gives the discounted Northern firm value as

$$
v_{N}=\frac{c_{N} N_{N}\left[1-\frac{w_{L}}{\lambda\left(1+\tau_{N}\right)}\right]+c_{S} N_{S}\left(\frac{1}{1+\tau_{S}}-\frac{w_{L}}{\lambda}\right)}{r+(1+B)(2 \imath+\mu)-\dot{v}_{N} / v_{N}} .
$$

\subsection{Balanced Trade}

We impose a balance-of-trade (BOT) condition to determine the relative consumer expenditure levels for both countries. More specifically, the BOT implies that the value of exports net of tariffs must be equal between the North and the South. In our continuum-of-industries setting, this gives:

$$
n_{N} \frac{c_{S} N_{S}}{\lambda} \underbrace{\frac{\lambda}{1+\tau_{S}}}_{=x_{S} N_{S}} \underbrace{1+\tau_{N}}_{=p_{N}^{S} /\left(1+\tau_{S}\right)})(n_{=x_{N} N_{N}}^{\frac{c_{N} N_{N}}{1+\tau_{N}}} \underbrace{\frac{1+\tau_{N}}{1+\tau_{N}}}_{=p_{S}^{N} /\left(1+\tau_{N}\right)},
$$


where the LHS (RHS) denotes the value of Northern (Southern) exports net of tariffs. To determine $n_{N}$, the industry share located in the North, we note that Northern entrepreneurs capture industry leadership from Southern firms at a rate of $\imath\left(1-n_{N}\right)$, while Southern firms capture industry leadership from Northern firms at a rate of $\mu n_{N}$. Constancy of industry shares in the steady state requires $\imath\left(1-n_{N}\right)=\mu n_{N}$, which implies

$$
n_{N}=\frac{l}{l+\mu}
$$

By using (16) and defining the relative Southern population size as $\eta_{S} \equiv N_{S} / N_{N}$, the above BOT condition can be rewritten as

$$
c_{R}=\frac{\imath \eta_{S}\left(1+\tau_{N}\right)}{\mu\left(1+\tau_{S}\right)} \quad \text { BOT }
$$

where $c_{R} \equiv c_{N} / c_{S}$ denotes the relative North-South consumption expenditure. We note the following relationships for future use:

- $\quad c_{R}$ is increasing in $t / \mu=n_{N} / n_{S}$ : an increase in the relative proportion of Northern industries $n_{N} / n_{S}$ raises the relative size of Northern exports, thereby increasing the relative Northern income available for consumption;

- $c_{R}$ is increasing in $\tau_{N}$ : a lower Northern import tariff $\tau_{N}$ reduces the prices of Southern exports in the Northern market, thereby increasing the amount of Southern exports and relative Southern income available for consumption;

- $\quad c_{R}$ is decreasing in $\tau_{S}$ : a lower Southern import tariff $\tau_{S}$ increases the Northern firms' profit margins net of tariffs, thereby increasing Northern export revenues and relative Northern income available for consumption;

- $c_{R}$ is increasing in $\eta_{S}$ : a larger relative size of the Southern market raises the relative export revenues of the North, thereby increasing relative Northern income available for consumption.

\subsection{Labor Markets 1: Equilibrium Conditions}

To close our model, we derive the labor market equilibria for both countries. In the North, decentralized wage bargaining can lead to trade-union induced unemployment. The general-purpose labor market equilibrium requires that $\left(1-S_{N}-u\right) N_{N}=L_{N}$ is always fulfilled, where $u \equiv U / N_{N}$ denotes the Northern unemployment rate, $U$ is the total number of Northern unemployed workers, and $L_{N}$ is Northern employment. 
The Northern demand for manufacturing labor is $n_{N}\left\{c_{N} N_{N} /\left[\left(1+\tau_{N}\right) \lambda\right]+c_{S} N_{S} / \lambda\right\}$, the Northern R\&D labor demand is, using (10), $a_{l} I=a_{l} l D$; hence the Northern general-purpose labor market equilibrium condition is

$$
L_{N}=\frac{n_{N}}{\lambda}\left(\frac{c_{N} N_{N}}{1+\tau_{N}}+c_{S} N_{S}\right)+a_{l} l D=\left(1-s_{N}-u\right) N_{N} .
$$

Obviously, the Northern bargained wage rate $w_{L}$ does not (directly) affect Northern production labor demand. The reason is that due to global Bertrand price competition, product prices are proportional to the marginal cost of the lowest-cost producers, which happen to be the Southern producers with marginal cost $w_{S} \equiv 1$.

Northern RPA labor demand is $n_{N} \gamma X$, hence the Northern specialized labor market equilibrium condition is

$$
n_{N} \gamma X=s_{N} N_{N}
$$

The Southern demand for manufacturing labor is $\left(1-n_{N}\right)\left[c_{S} N_{S}+c_{N} N_{N} /\left(1+\tau_{N}\right)\right]$. Given that Southern imitation does not require any resources, the Southern labor market (SLM) equilibrium condition is

$$
\left(1-n_{N}\right)\left(c_{S} N_{S}+\frac{c_{N} N_{N}}{1+\tau_{N}}\right)=N_{S} \quad \text { SLM. }
$$

\subsection{Labor Markets 2: Wage Bargaining in the North}

There is decentralized wage bargaining between any new incumbent Northern firm and a centralized labor union who bargains on behalf of Northern general-purpose workers. The sequence of events is as follows. First, when an entrepreneur firm enters the R\&D race, it employs general-purpose workers at the going wage rate $w_{L}$ to perform $\mathrm{R} \& \mathrm{D}$ services. There is nothing to bargain between entrepreneurs and $\mathrm{R} \& \mathrm{D}$ workers due to free entry in R\&D races and thus zero expected profits. Second, if the entrepreneur becomes successful in innovating, it has to bargain with the production workers before any production starts. This is because there are positive expected monopoly profits and workers are represented by a labor union. In the meanwhile, the previously employed $R \& D$ workers of the successful innovator can find employment (either in a new R\&D firm or in a producing firm which may as well be the successful innovator) or they can become unemployed (if the bargained wage rate exceeds the competitive wage rate). When bargaining, the prospective production workers take the industry-wide innovation rate as given since it is 
beyond control of a single firm. ${ }^{12}$ Third, after the wage bargaining is settled, the firm decides about the level of manufacturing employment and starts production. ${ }^{13}$ The bargained wage rate, although determined individually between a single firm and the labor union, will be the same across all firms because they face a symmetric problem and have identical bargaining power.

The bargained Northern general-purpose wage rate $w_{L}$ is derived from the Nash maximand

$$
\Omega=\left(\frac{W_{N}}{r}-\bar{W}_{N}\right)^{\alpha}\left(v_{N}-\bar{v}_{N}\right)^{1-\alpha} \rightarrow \max _{w_{L}} !
$$

$\alpha \in\left[0,1\left[\right.\right.$ is the relative bargaining power of the labor union, and $W_{N} \equiv\left(w_{L}-w^{\min }\right)^{\theta}\left[\left(1-s_{N}-u\right) N_{N}\right]^{\chi}$ is the expected excess-wage income received by the union members, where excess wage and employment levels are evaluated by the elasticities of the underlying utility function of the labor union, respectively. ${ }^{14}$ The minimum wage rate $w^{\text {min }}>1$ is set by the government, and we assume that $w^{\text {min }}$ is credibly enforced by law such that it serves as the natural reference point for the labor union. ${ }^{15} \bar{W}_{N}$ is the workers' discounted per-period income during the negotiations on $w_{L}$ or during a strike - their 'inside option' (and not what they would get if they unilaterally quit the negotiations without agreement - their 'outside option, ${ }^{16}$ ), and

${ }^{12}$ The same is true with respect to the economy-wide unemployment rate which will be derived as a function of the aggregate innovation rate. The individual firm's innovation rate is also exogenous to the bargaining process since for producing firms, the innovation is a past event and it no longer invests in R\&D in this industry. This is the standard Arrow inertia effect.

${ }^{13}$ Since the Northern firms' production labor demand (18) does not (directly) depend on $w_{L}$, there is no pass-through of higher Northern production costs to product prices, which would reduce consumption and hence the individual Northern firm's general-purpose labor demand. Thus, in our setting it does not matter whether the firm is granted the "right to manage" employment ex-post or ex-ante wage bargaining.

${ }^{14}$ The underlying labor union's objective is a Stone-Geary type utility function $U\left(w_{L}, L_{N}\right)=\left(w_{L}-w^{\min }\right)^{\theta} L_{N}{ }^{\chi}$, where $\theta$ $\geq 0$ and $\chi \geq 0$ represent, respectively, the union's preference for excess wages and employment, cf. Mezzetti and Dinopoulos (1991, p. 82).

${ }^{15}$ Lingens (2003) takes as the union's reference wage the competitive wage rate derived from a hypothetical situation with no wage bargaining. This requires truly heroic rationality of labor unions since the competitive wage rate cannot be observed in such a setting, while the minimum wage rate can be observed (by looking into the text of law) even without actually being paid to anybody. In the trade literature with unions (Mezzetti and Dinopoulos 1991, Zhao 1998, 2001), the union's reference wage is derived from a second sector that is perfectly competitive and non-unionized. This modeling renders the reference wage a real and observable option but complicates the analysis and removes unemployment from the model. Palokangas $(1996,2004,2005)$ neglects such a reference point altogether, which has the downside that for $\alpha=0$, the bargained wage rate becomes zero.

${ }^{16}$ Palokangas (2004, p. 205, fn. 6), with reference to Binmore at al. (1986, p. 186-187), points out that taking the expected income outside the firm as the union's reference point would not be correct since it "[...] is not in line with the microfoundations of the alternating offers game". Instead, it is "[...] appropriate to identify the reference income with the income streams accruing to the parties in the course of the dispute". The outside option for the workers (unemployment benefits, wage income elsewhere) if the firm and the labor union fail to agree on a wage rate is an irrelevant alternative and "[...] has no effect on the bargain, provided the bargain gives both parties 
$\bar{v}_{N}$ is the discounted Northern firm's profits during the negotiation or a strike. We assume that employed workers do not have any income during wage negotiations (i.e., we abstract from any strike funds of the labor union). Moreover, possible one-time redundancy payments to those workers just laid off do not matter in this respect since they are not paid under the condition that the bargaining process takes another period, hence $\bar{W}_{N}=0$. Similarly, $\bar{v}_{N}=0$ since Northern firms cannot manufacture without agreement on $w_{L}$. Using these identities in (21), and substituting for $v_{N}$ from (15) simplifies the bargaining problem to

$$
\Omega=\left\{\frac{\left(w_{L}-w^{\min }\right)^{\theta}\left[\left(1-s_{N}-u\right) N_{N}\right]^{\chi}}{r}\right\}^{\alpha}\left\{\frac{c_{N} N_{N}\left[1-\frac{w_{L}}{\lambda\left(1+\tau_{N}\right)}\right]+c_{S} N_{S}\left(\frac{1}{1+\tau_{S}}-\frac{w_{L}}{\lambda}\right)}{r+(1+B)(2 \imath+\mu)-\dot{v}_{N} / v_{N}}\right\}^{1-\alpha} \rightarrow \max _{w_{L}} !
$$

The first order condition is

$$
\frac{\alpha \theta}{w_{L}-w^{\min }}\left\{c_{N} N_{N}\left[1-\frac{w_{L}}{\lambda\left(1+\tau_{N}\right)}\right]+c_{S} N_{S}\left(\frac{1}{1+\tau_{S}}-\frac{w_{L}}{\lambda}\right)\right\}=(1-\alpha)\left[\frac{c_{N} N_{N}}{\lambda\left(1+\tau_{N}\right)}+\frac{c_{S} N_{S}}{\lambda}\right],
$$

which implies that the increase in the firm's profits extraction by the labor union through a marginal increase in $w_{L}-w^{\min }$, evaluated by the union's share $\alpha$ in $\Omega$ and the union's excess wage preference $\theta$ (LHS), must equal the increase in the firms' production costs by this marginal increase in $w_{L}-w^{\text {min }}$, evaluated by the firm's share $1-\alpha$ in $\Omega$ (RHS). ${ }^{17}$ For the remainder of the paper, we normalize $\theta \equiv 1$ without loss of generality. By using the BOT condition (17) in (23) and simplifying terms, we find the negotiated Northern unskilled wage rate as

$$
w_{L}=\frac{\alpha \lambda\left[\imath\left(1+\tau_{N}\right)+\mu\right]}{\imath+\mu\left(1+\tau_{S}\right)}+(1-\alpha) w^{\min } \quad \forall \alpha \in[0,1], \quad \text { given } \frac{\lambda\left[\imath\left(1+\tau_{N}\right)+\mu\right]}{\imath+\mu\left(1+\tau_{S}\right)} \equiv w^{\max }>w^{\min },
$$

where $w^{\max }$ is the maximum wage rate that would apply for $\alpha \rightarrow 1$, which leaves zero profits for Northern incumbent firms and thus would destroy any innovation incentives of entrepreneurs. For the rest of the paper we maintain $w^{\max }>w_{L}>w^{\min }$ to study the impact of bargaining on employment and growth in a meaningful way.

Obviously, the bargained wage rate $w_{L}$ is increasing in the labor union's bargaining power $\alpha$ and the fallback value $w^{\min }$. To explain the remaining properties of $w_{L}$ in (24), we rewrite (23) with $\theta \equiv 1$ as fol-

more than they could get elsewhere" (Layard et al. 2005, p. 100). See also Cahuc and Zylberberg (2004, p. 389), or Hall and Milgrom (2008) on this argument.

${ }^{17}$ Obviously, the second derivative of (22) with respect to $w_{L}$ is negative, hence the f.o.c. is also sufficient for a maximum. 
lows:

$$
\alpha\left(R-w_{L} Q\right)=(1-\alpha) Q\left(w_{L}-w^{\min }\right) \quad \Leftrightarrow \quad w_{L}=\alpha \frac{R}{Q}+(1-\alpha) w^{\min },
$$

where $R \equiv c_{N} N_{N}+c_{S} N_{S} /\left(1+\tau_{S}\right)$ denotes the total sales revenues per Northern industry, and $Q \equiv$ $c_{N} N_{N} /\left[\lambda\left(1+\tau_{N}\right)\right]+c_{S} N_{S} / \lambda$ denotes the total quantity produced per Northern industry. It follows that $R / Q$ is the average revenue received by Northern firms on both markets. Obviously, $w_{L}$ is increasing in $R / Q$ because a higher average revenue expands the size of the pie over which firms and workers bargain. Using the BOT condition (17), $R / Q$ can be written as a function of $c_{R} \equiv c_{N} / c_{S}$ :

$$
\frac{R /\left(c_{S} N_{S}\right)}{Q /\left(c_{S} N_{S}\right)}=\frac{\lambda\left(\frac{c_{R}}{\eta_{S}}+\frac{1}{1+\tau_{S}}\right)}{\frac{c_{R}}{\eta_{S}\left(1+\tau_{N}\right)}+1} .
$$

A decrease in $\tau_{N}$ has three effects on the Northern bargained wage rate $w_{L}$. The first two are triggered by the reduction in the relative North-South expenditure $c_{R}$, which follows from the BOT condition (17). First, a lower $c_{R}$ implies a reduction in Northern total sales revenues relative to Southern consumption expenditure $R /\left(c_{S} N_{S}\right)$, which reduces the average revenue $R / Q$ received by Northern firms and hence $w_{L}$. Second, a lower $c_{R}$ implies a reduction in Northern total quantity produced relative to Southern consumption expenditure $Q /\left(c_{S} N_{S}\right)$, which raises the average revenue $R / Q$ received by Northern firms and hence $w_{L}$. The third effect is triggered by the direct impact of Northern tariffs on prices. A lower $\tau_{N}$ reduces the price charged in the Northern market and thus raises the total quantity sold relative to $c_{S} N_{S}$. This reduces the average revenue $R / Q$ received by Northern firms and hence $w_{L}$. As can immediately be seen from the reduced form (24), the first and third effects dominate the second, and the net effect is a decrease in $w_{L}$. Hence, with wage bargaining, our model establishes a positive link between Northern import tariffs and Northern general-purpose wages, ceteris paribus. A decrease in $\tau_{S}$ simply reverses all three effects and thus increases $w_{L}$.

An increase in the Northern innovation rate $\imath$ raises $c_{R}$, which raises both revenues $R /\left(c_{S} N_{S}\right)$ and production quantity $Q /\left(c_{S} N_{S}\right)$ relative to Southern consumption expenditure. For positive tariff rates, the revenue effect dominates the quantity effect, and hence $w_{L}$ increases with higher $t$. The reasoning for why $w_{L}$ declines with higher $\mu$ is analogous. We summarize our results in

Lemma 1: The bargained wage rate $w_{L}$ is increasing in $\alpha, w^{\min }, \tau_{N}$, and $l$; it is decreasing in $\tau_{S}$ and $\mu$. 


\subsection{Steady-State Equilibrium}

We solve the model for an interior steady-state equilibrium where the endogenous variables $c_{N}, c_{S}, u \in(0$, $1), l, n_{N}, w_{L}$ and $w_{H}$ are non-negative and remain constant. $\pi_{N}(t), \pi_{N}^{N}(t), \pi_{N}^{S}(t), X(t), D(t)$ and $v_{N}(t)$ are also non-negative and grow at a common rate of $n$, and $r=\rho$.

We first derive reduced-form expressions for $c_{N}$ and $c_{S}$ by using (16) and the BOT condition (17) in the Southern labor market clearing condition (20). This yields

$$
c_{N}=\frac{\imath \eta_{S}(l+\mu)\left(1+\tau_{N}\right)}{\mu\left[\imath+\mu\left(1+\tau_{S}\right)\right]},
$$

which is unambiguously increasing in $\iota, \eta_{S}$ and $\tau_{N}$, and decreasing in $\mu$ and $\tau_{S}$. Also, we find

$$
c_{S}=\frac{(l+\mu)\left(1+\tau_{S}\right)}{\imath+\mu\left(1+\tau_{S}\right)},
$$

which is unambiguously increasing in $t$ and $\tau_{S}$, and decreasing in $\mu .{ }^{18}$

To explain the properties of (25) and (26), we plot the BOT condition (17) and the SLM condition (20) in $\left(c_{N}, c_{S}\right)$ space in Figure 1. The BOT curve is upward sloping, capturing the $c_{R} \equiv c_{N} / c_{S}$ ratio implied by balanced trade for given $l$. The SLM curve is downward sloping, capturing the trade-off between $c_{N}$ and $c_{S}$ in the context of Southern resource equilibrium for a given level of $t$.

A lower Northern tariff rate $\tau_{N}$ leads to a decrease in $c_{R}$, turning the BOT curve clockwise. The increased demand for Southern exports triggered by the lower $\tau_{N}$ boosts labor demand in the South. Restoring equilibrium requires a fall in $c_{N}$ for given $c_{S}$, which turns the SLM curve counterclockwise around the abscissa intercept $1 / n_{S}$. Clearly, the net effect is that $c_{N}$ goes down, and it follows from (26) that the effects on $c_{S}$ exactly cancel out such that $c_{S}$ remains constant.

A lower Southern tariff rate $\tau_{S}$ increases $c_{R}$, turning the BOT curve counterclockwise. Southern tariffs have no influence on the SLM condition. Thus, the net effects are that $c_{S}$ declines and $c_{N}$ increases.

\footnotetext{
${ }^{18}$ Note that with free trade, $c_{S}=w_{S}=1$. Hence the BOT condition is equivalent to "balanced asset ownership": Northern people hold only assets of Northern firms and Southern people hold only assets of Southern firms. Since there is perfect competition in Southern imitation-based products, the value of Southern firms and thus the value of Southern assets is equal to zero.
} 


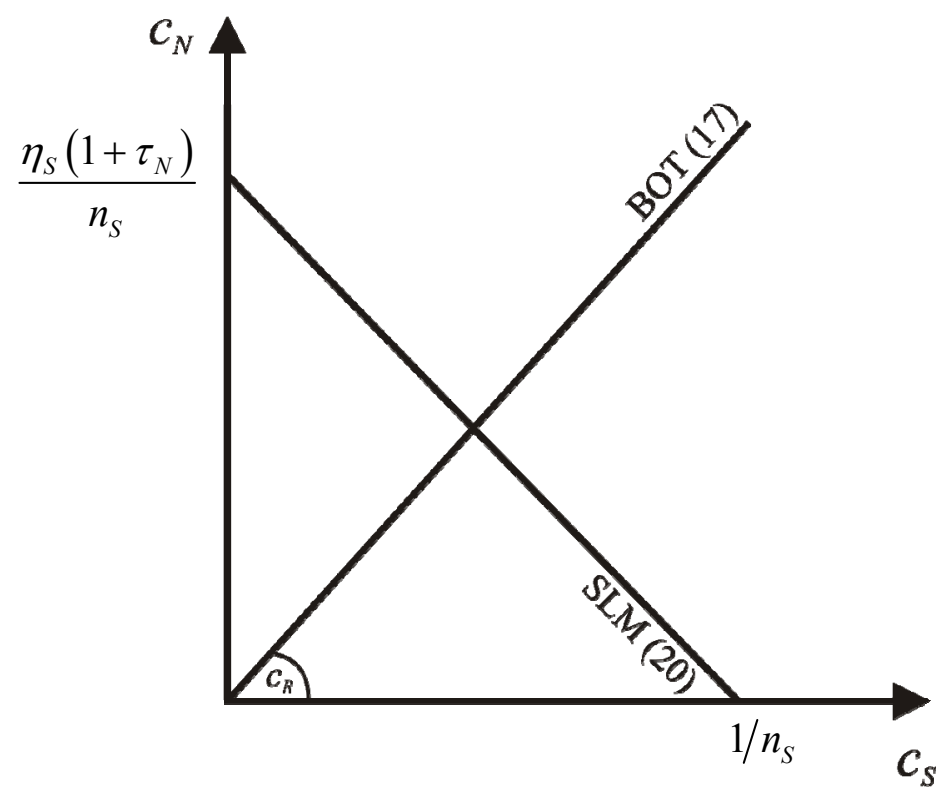

Figure 1: The determination of $c_{N}(l)$ and $c_{S}(l)$

An increase in the relative size of the Southern market $\eta_{S}$ raises $c_{R}$, turning the BOT curve counterclockwise. A higher $\eta_{S}$ also implies a relative expansion of Southern resources. For a given $c_{S}$, this allows for an increase in $c_{N}$ and turns the SLM curve clockwise around the abscissa intercept $1 / n_{S}$. Obviously, the net effect is that $c_{N}$ increases, and it follows from (26) that the effects on $c_{S}$ exactly cancel out such that $c_{S}$ remains constant.

A higher Southern imitation rate $\mu$ leads to a decrease in $c_{R}$, turning the BOT curve clockwise. As the share of Southern industries $n_{S}$ increase with the higher $\mu$, the demand for Southern labor increases. For a given $c_{S}$, restoring the Southern labor market equilibrium requires a lower $c_{N}$. Hence, the SLM curves shifts down. As a result, $c_{N}$ decreases, and it follows from (26) that the net effect on $c_{S}$ is negative as well. Finally, a higher innovation rate $\imath$ triggers the exact opposite forces and thereby leads to higher levels of both $c_{N}$ and $c_{S}$.

Now we can reduce the Northern general-purpose labor market clearing condition (18) to an equation in only two endogenous variables, $\imath$ and $u$. Using (16) to substitute for $n_{N}$, (17) to substitute for $c_{S}$, (25) to substitute for $c_{N}$, (9) to substitute for $D$ and (19) to substitute for $X$, gives, after simplifying, the Northern steady-state unemployment rate $u^{*}$ as a decreasing function of the innovation rate:

$$
u^{*}=1-s_{N}-\imath^{*}\left(\frac{\eta_{S}}{\lambda \mu}+A_{\iota}\right)>0,
$$


where $A_{t} \equiv a_{t} \delta s_{N} /(n \gamma)$ captures the effective resource requirement per unit of R\&D (so that $\iota A_{t}$ is the per-capita R\&D labor demand). Since we impose $w_{L}>w^{\text {comp }}$ (to be validated by our later numerical simulation), it follows $\left.\left.u^{*}>0 \forall \alpha \in\right] 0,1\right]$. $^{19}$

Next, we substitute $v_{N}$ from (11) into (14) and use (9) to substitute for $D$. This gives the Northern specialized-labor wage rate as an increasing function of $w_{L}$ and $t$ :

$$
w_{H}=w_{L}\left(1-\sigma_{\imath}\right) A_{l} \iota^{2}(1+B) / s_{N} \text {. }
$$

To determine the steady-state innovation rate $i^{*}$, we set (15) equal to (11), use (17) to substitute for $c_{S}$, (25) to substitute for $c_{N}$, (24) to substitute for $w_{L}$, (9) to substitute for $D,(19)$ to substitute for $X$, and use the steady-state results $r=\rho$ and $\dot{v}_{N} / v_{N}=n$. This yields the free-entry in innovation (FEIN) condition as an implicit function that pins down $i^{*}$ solely in terms of exogenous parameters:

$$
\begin{aligned}
& \frac{\frac{\eta_{S}(\imath+\mu)}{\mu \lambda}\left[\frac{1}{\alpha+(1-\alpha) \frac{w^{\min }}{w^{\max }}}-1\right]}{\rho+(1+B)(2 \imath+\mu)-n}=\left(1-\sigma_{\iota}\right) A_{\iota} \quad \text { FEIN }(\imath) \\
& \Rightarrow \iota^{*}=\iota^{*}\left(\begin{array}{c}
w^{\min }, \alpha, B, \tau_{N}, \tau_{S}, \mu, \eta_{S} \\
---+--+
\end{array}\right) .
\end{aligned}
$$

The LHS of (29) gives the discounted R\&D benefit divided by $w_{L}$, and the RHS of (29) gives R\&D costs divided by $w_{L}$. As is demonstrated in Appendix A, the signs indicated below (29) follow from implicit differentiation under sufficiently low tariff rates ${ }^{20}$ if, and only if,

$$
\rho-n<(1+B) \mu
$$

is fulfilled. This turns out to be the condition for stability of equilibrium ${ }^{21}$ and thus will be maintained for the rest of this paper.

\footnotetext{
${ }^{19}$ The competitive wage rate $w^{\text {comp }}$ is the wage rate that clears the labor market under no bargaining. Any higher bargained wage rate $w_{L}>w^{\text {comp }}$ (which justifies the existence of a trade union) raises $\mathrm{R} \& \mathrm{D}$ and production costs without increasing revenues of successful entrepreneurs, which unambiguously reduces R\&D incentives. The resulting decrease in $\imath$ reduces R\&D and production labor demand (the latter by reducing the share of Northern industries, inter alia) in the North, which implies $u^{*}>0$ in equilibrium.

${ }^{20}$ This restriction means that we are able to formally establish this result for $\tau_{N}=\tau_{S}=0$, but obviously it holds for a full range of tariff rates, although the exact boundaries cannot be determined.

${ }^{21}$ Technically, this assumption - as well as the assumption of sufficiently low tariff rates - is necessary to ensure that the implicit function $f\left({ }^{*}, \ldots\right)=0$ derived from (29) is monotonously decreasing in $\imath^{*}$. Intuitively, an increase in $\imath$ must reduce the profitability of innovative R\&D expenditure in order to yield a stable solution for $l$. Thus, the sig-
} 
The remaining endogenous variables are determined recursively for given ${ }^{*}$ in the following order. $u^{*}$ follows from (27), $w_{L}{ }^{*}$ follows from (24), $n_{N}{ }^{*}$ follows from (16), $c_{N}{ }^{*}$ and $c_{S}{ }^{*}$ follow from (25) and (26), $v_{N}{ }^{*}$ follows from (15), $\pi_{N}^{P *}$ follows from (6), $w_{H}{ }^{*}$ follows from (28), $X^{*}$ follows from (14), and $D^{*}$ follows from (9). Finally, the common steady-state utility growth rate is derived as usual from (2) as $g^{*}=$ $\dot{f}_{N} / f_{N}=\dot{f}_{S} / f_{S}=\imath^{*} \log \lambda$.

The properties of the steady-state innovation and unemployment rates are very intuitive. A decrease in the minimum wage rate $w^{\min }$ raises $\imath^{*}$. A lower minimum wage rate worsens the effective bargaining power of the union, and thereby leads to a lower Northern wage rate $w_{L}$. This reduces both R\&D and production costs, and thus increases $l^{*}$. For the same reason, $\imath^{*}$ is decreasing in the bargaining power $\alpha$ of the labor union. A larger liquidation $\operatorname{cost} B$ reduces $\imath^{*}$ via two channels: first, it reduces $v_{N}$ in (13) by increasing the capital loss of the firm when imitation or further innovation take place. Second, incumbent firms react to a larger $B$ by increasing their RPA expenditure in (14), which leads to a further decline in $v_{N}$.

A decrease in the Northern import tariff $\tau_{N}$ exerts multiple effects on R\&D profitability. First, it forces the Northern incumbent to reduce its markup in the domestic market, lowering the profit flows $\pi_{N}$. This is reinforced by the reduction in $c_{N}$ which is triggered by the fall in $\tau_{N}$. With profit sharing in place, the firm can pass on the lower profits to workers in the form of a lower bargained wage rate $w_{L}$ (Lemma 1). This works to mitigate the fall in $\pi_{N}$ by reducing both R\&D and production costs. Provided that $w_{L}$ contains an exogenous component like $w^{\text {min }}$ (to be discussed in more detail further below), the net impact is a reduction in R\&D profitability and thus a lower Northern import tariff $\tau_{N}$ leads to a lower $l^{*}$.

A decrease in the Southern import tariff $\tau_{S}$ can be analyzed similarly. A lower $\tau_{S}$ increases $\pi_{N}$ by increasing the after-tariff price enjoyed by the Northern incumbent in the Southern market and also by triggering an increase in $c_{N}$. This is mitigated by a higher bargained wage rate $w_{L}$ and lower $c_{S}$. Again, provided that $w_{L}$ contains an exogenous component like $w^{\text {min }}$, the net impact is an increase in R\&D incentives, and thus a lower Southern import tariff $\tau_{S}$ leads to a higher $\imath^{*}{ }^{22}$

An increase in the Southern imitation rate $\mu$ has several effects on $i^{*}$. It raises the replacement rate and thereby reduces the rewards from innovating $v_{N}$ in (13). This effect is further strengthened by the re-

nificance of condition (30) is to ensure, together with (A.6) and (A.7) from Appendix A, the existence and uniqueness of the steady-state equilibrium in the neighborhood of free trade.

${ }^{22}$ Appendix R.2 (available upon request) shows that bilateral trade liberalization has an ambiguous effect on $i^{*}$. However, our numerical simulation in section 2.12 suggests that for reasonable parameter values, the net impact of bilateral trade liberalization with equi-proportionate tariff cuts is to increase $l^{*}$. 
ductions in both $c_{N}$ and $c_{S}$, which decrease $\pi_{N}$. The firm passes the decline in its profit flows to workers and bargains for a lower wage rate $w_{L}$ (Lemma 1). However, this does not dominate the negative effects and the net profitability of R\&D declines. Consequently, a higher Southern imitation rate $\mu$ decreases $\imath^{*}$. An increase in the relative size of the Southern economy $\eta_{S}$ increases $c_{N}$ and hence generates larger profits from domestic sales in the North. This increases innovation incentives and thus $l^{*}{ }^{23}$

We now briefly discuss those determinants of the steady-state unemployment rate $u^{*}$ given in (27) which are of main interest. First, a decrease in the labor union's bargaining power $\alpha$ or the minimum wage rate $w^{\min }$ unambiguously reduces $u^{*}$ by increasing $\imath^{*}$. A higher $\imath^{*}$ raises production employment by increasing the proportion of Northern industries $n_{N}$ and the levels of per-capita consumption expenditure, $c_{N}$ and $c_{S}$. These effects work to boost the demand for Northern labor in manufacturing. In addition, the higher R\&D intensity $\imath^{*}$ directly raises R\&D labor demand. There is no union impact on $u^{*}$ other than through raising $l^{*}$ since the bargained wage rate does not affect Northern supply prices. Second, an increase in liquidation costs $B$ raises $u^{*}$ by reducing $\imath^{*}$. Third, Northern (Southern) unilateral trade liberalization $\tau_{N} \downarrow$ $\left(\tau_{S} \downarrow\right)$ increases (decreases) Northern unemployment by reducing (raising) $\imath^{*} \cdot{ }^{24}$ Fourth, an increase in the Southern imitation rate $\mu$ raises $u^{*}$ since it reduces the proportion of Northern industries $n_{N}$ both directly and indirectly, by decreasing $\imath^{*}$. This unemployment-generating effect is reinforced by the decline in $c_{N}$ and $c_{S}$ triggered by the higher $\mu$. Fifth, an increase in $\eta_{S}$ reduces $u^{*}$ directly by expanding the Southern consumption expenditure per unit of Northern labor $c_{S} \eta_{S}$, and indirectly by increasing $c_{N}$ and $\imath^{*}$. Summarizing the main arguments, we have derived our $^{25}$

${ }^{23}$ A higher $\eta_{S}$ captures the increased Southern presence in the world trading system and is thus considered as one form of globalization (see Dinopoulos and Segerstrom 2007, and Lu 2007). In our companion paper with flexible labor markets, Grieben and Şener (2009), we found the same results as in here: a higher $\eta_{S}$ raises ${ }^{*}$. However, when we differentiated between innovation-deterring and imitation-deterring activities as Northern-resource-using and Southern-resource-using activities, respectively, we found that a higher $\eta_{S}$ can actually lower the rates of innovation and worldwide growth.

${ }^{24}$ It should be noted that a lower $\tau_{N}$ 's direct impact is to increase Northern labor demand by lowering the mark-up price charged by Northern producers in the North. However, this effect is exactly nullified by the reduction in $c_{N}$ which is triggered by the lower $\tau_{N}$, see equations (18) and (25). A lower $\tau_{S}$ also exerts competing effects on Northern labor demand by increasing $c_{N}$ and decreasing $c_{S}$, see equations (25) and (26). These two effects exactly cancel out as well. Hence, tariff changes affect $u^{*}$ only via their impact on $\imath^{*}$.

${ }^{25}$ In Appendix R.1, we check the robustness of our results by endogenizing the Southern imitation rate. We find that this leads to a more differentiated view on the growth and employment effects of globalization. While the effects of changing import tariffs on innovation and growth are unaffected from endogenizing the Southern imitation rate, the effects of an increased presence of the South on the world trade markets are reversed. 
Proposition 1: Starting from a unique steady-state equilibrium with an interior solution and sufficiently low tariff rates, we find that the following changes lead to faster Northern innovation and worldwide growth and lower Northern unemployment:

i.) an increase in the relative size of the South $\eta_{S}$;

ii.) an increase in the Northern import tariff rate $\tau_{N}$;

iii.) a decrease in the Southern import tariff rate $\tau_{S}$;

iv.) a decrease in the Southern imitation rate $\mu$;

v.) a decrease in the labor union's bargaining power $\alpha$ or the minimum wage rate $w^{\text {min }}$;

vi.) a decrease in the liquidation costs $B$;

vii.) an increase in the $R \& D$ subsidy rate $\sigma_{l}$.

As we show in Appendix B, when the competitive wage rate $w^{\text {comp }}$, given in (B.1), is used instead of $w_{L}$ to derive the FEIN condition (29), then tariffs would not matter anymore for the steady-state innovation rate $\imath^{*}$, hence the "tariff-neutrality" result of our companion paper Grieben and Şener (2009) would be reestablished.

To explain why tariffs do matter under wage bargaining, we note that the bargained wage rate $w_{L}$ given in (24) contains a rigid component $w^{\min }>0$ which drives a wedge between tariff effects on discounted $R \& D$ benefits and those on R\&D costs. Consider for example Northern trade liberalization. A decrease in $\tau_{N}$ reduces the discounted profits of a Northern quality leader from domestic sales by more than it reduces the marginal R\&D-cost component $w_{L}$, simply because the minimum-wage component of $w_{L}$ is insensitive to tariff changes. Conversely, a decrease in $\tau_{S}$ increases the discounted profits of a Northern quality leader from foreign sales by more than it increases the marginal R\&D-cost component $w_{L}$. The consequences of these tariff effects for mercantilist attitudes of the North are analyzed in detail in section 2.11 below.

Unemployment benefits can play a role similar to minimum wages in our context. Nickell (2003, p. 19, Table 4) provides evidence of a clear upward trend of unemployment benefit replacement ratios within the period $1960-1999$ in many OECD countries. If the expected per-period income $E\left[w_{L}\right] \equiv(1-u) w_{L}+$ $u b w_{L}$ is considered by the labor union as the reference wage income in the wage bargaining problem (21) instead of $w^{\min }$, with $\left.b \in\right] 0,1[$ denoting an unemployment benefit parameter, then the resulting steadystate solutions for the bargained wage rate $\hat{w}_{L}$ and the innovation rate $\hat{\imath}$ would be those given in (24) and (29) with $w^{\min }=0$ imposed, respectively. Hence, tariff neutrality would apply again. However, if we assume instead that the per-period unemployment benefit is independent of the bargained wage rate (such that $E^{\prime}\left[w_{L}\right] \equiv(1-u) w_{L}+u b$ is taken as reference value in (21) instead of $\left.w^{\min }\right)$, then the resulting steadystate solutions for the bargained wage rate $w_{L}$ ' and the innovation rate $l^{\prime}$ would be qualitatively identical to 
those in our actual framework, only with $w^{\text {min }}$ being replaced by $b$ in (24) and (29), respectively. In that case, $b$ would take over the role of $w^{\min }$ in terms of driving a wedge between the effects of any changes in tariff rates $\tau_{N}$ and $\tau_{S}$ on discounted R\&D benefits, and their effects on R\&D costs. Hence, for tariff neutrality to break down, the reference wage income must contain at least one term that is independent of the bargained wage rate itself, may it be $w^{\min }$ or $b$. Actually, for breaking the tariff-neutrality result it would be sufficient to have only a fraction of $w^{\text {min }}$ or $b$ being independent of $w_{L}$, e.g. $w^{\min } \equiv \beta w_{L}+(1-\beta) m$, with $\beta$ $\in] 0,1[$ and $m>0$ being exogenous. We summarize these findings in

Proposition 2: Tariff changes can only have an impact on Northern steady-state innovation and unemployment rates as described in Proposition 1 if the reference wage considered by the labor union in the bargaining problem (21) contains an element (like a minimum wage rate $w^{\text {min }}$ or a fixed unemployment benefit $b$ ) that is independent of the bargained wage rate itself.

\subsection{Steady-State Welfare Analysis}

As we show in Appendix R.3 (available upon request), Northern per-capita steady-state welfare can be expressed as a function

$$
F_{N}=\frac{1}{\rho}\left[\frac{\imath \log (\lambda)}{\rho}+\left(1-n_{N}\right) \log \left(\frac{c_{N}}{p_{S}^{N}}\right)+n_{N} \log \left(\frac{c_{N}}{p_{N}^{N}}\right)\right],
$$

which consists of static and dynamic components. The dynamic welfare component is $t \log \lambda$. In the continuum of industries, quality improvements arrive at a rate of $l$, and each improvement raises the consumer's utility by $\log \lambda$. The static welfare component is the logarithm of purchased goods summed over industries. In a fraction $1-n_{N}$ of industries, the Northern consumer faces a price of $p_{S}^{N}=1+\tau_{N}$ and purchases $c_{N} / p_{S}^{N}$ units. In the remaining fraction $n_{N}$ of the industries, she faces a price of $p_{N}^{N}=\lambda\left(1+\tau_{N}\right)>$ $p_{S}^{N}$ and buys $c_{N} / p_{N}^{N}$ units.

Unilateral trade liberalization by the North has competing welfare effects on the components of (31). First, a decrease in $\tau_{N}$ reduces the frequency of quality improvements $t$ and generates a dynamic welfare loss. Second, the lower $\imath$ decreases $c_{N}$ as seen in equation (25), causing a static welfare loss. Finally, the lower $\imath$ raises $1-n_{N}$ and thus reduces the consumers' exposure to relatively high-priced Northern products, causing a static welfare gain. We note that a lower $\tau_{N}$ has no direct effect on quantities consumed $c_{N} / p_{N}^{N}$ and $c_{N} / p_{S}^{N}$ since a decline in $\tau_{N}$ decreases $c_{N}$ and the relevant product price proportionally. 
There is no terms-of-trade effect of a lower $\tau_{N}$ since the Northern net-of-tariff import price $p_{S}^{N} /\left(1+\tau_{N}\right)=1$ does not change.

Unilateral trade liberalization by the South also exerts competing effects, mostly working in the opposite direction. First, a decrease in $\tau_{S}$ increases $\imath$ and generates a dynamic welfare gain. Second, the higher $\imath$ raises $c_{N}$ as seen in equation (25), causing a static welfare gain. Third, the higher $\imath$ reduces $1-n_{N}$, causing a static welfare loss. Finally, a lower $\tau_{S}$ increases both $c_{N} / p_{N}^{N}$ and $c_{N} / p_{S}^{N}$ by increasing $c_{N}$ without affecting Northern product prices. This causes a static welfare gain. The increase in $c_{N}$ is triggered by a Northern terms-of-trade improvement due to the rise in the Northern net-of-tariff export price $\lambda /\left(1+\tau_{S}\right)$.

Using (16) to substitute for $n_{N}, p_{S}^{N}=1+\tau_{N}, p_{N}^{N}=\lambda\left(1+\tau_{N}\right)$, and (25) to substitute for $c_{N}$ in (31) gives, after rearranging terms,

$$
F_{N}=\frac{1}{\rho}\left\{l \log (\lambda)\left(\frac{1}{\rho}-\frac{1}{\imath+\mu}\right)+\log \left[\frac{\imath \eta_{S}(l+\mu)}{\mu\left[\imath+\mu\left(1+\tau_{S}\right)\right]}\right]\right\} \quad \rightarrow \max _{\tau_{N}}
$$

The relevant f.o.c. of the Northern government, after simplifying, is

$$
\frac{\partial F_{N}}{\partial \tau_{N}}=\frac{1}{\rho}\left\{\log (\lambda)\left[\frac{1}{\rho}-\frac{\mu}{(\imath+\mu)^{2}}\right]+\frac{t^{2}+\mu\left(1+\tau_{S}\right)(2 \imath+\mu)}{\imath(\imath+\mu)\left[\imath+\mu\left(1+\tau_{S}\right)\right]}\right\} \underbrace{\frac{\partial \imath}{\partial \tau_{N}}}_{>0}=0 .
$$

Clearly

$$
(l+\mu)^{2}>\rho \mu
$$

is sufficient for (33) to yield a corner solution that implies to choose the highest feasible $\tau_{N}=\tau_{N}^{\max }$ that is consistent with an interior steady-state equilibrium. ${ }^{26}$ Our numerical simulation below shows that condition (34) is indeed fulfilled for a wide range of plausible parameter values. ${ }^{27}$ This establishes that the Northern government favors protectionism to maximize its steady-state welfare as captured by (32).

${ }^{26}$ According to our assumption of section 2.3, $\tau_{N}<w_{L}-1$ should set the upper bound for $\tau_{N}$. However, since the steady-state innovation rate $\imath^{*}$ is increasing in $\tau_{N}$, and the steady-state unemployment rate $u^{*}$ is decreasing in $\imath^{*}$, the effective upper bound $\tau_{N}^{\max }$ for $\tau_{N}$ is where it has increased $\iota^{*}$ to the level $l^{\max }$ that implies $u^{*}=0$ in (27). For the benchmark parameters of our simulation below, this latter restriction is the more binding one.

${ }^{27}$ Note that since we do not directly optimize over $l$ (which would give the social-planner solution), we study here a constrained optimum where the market allocation mechanism for the various flows of labor is allowed for (i.e., 
The Northern government cannot directly choose $\tau_{S}$; however, during trade negotiations it can push for the level of $\tau_{S}$ that maximizes its welfare. To find this level, we derive the relevant f.o.c.

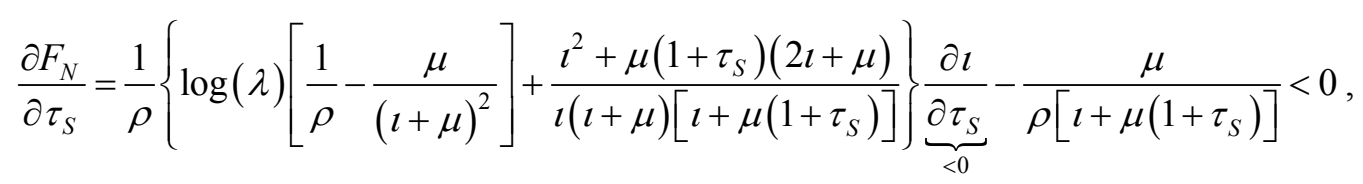

for which (34) is again a sufficient condition. This shows that the North favors the lowest feasible $\tau_{S}=$ $\tau_{S}^{\min }$ that is consistent with an interior steady-state equilibrium. ${ }^{28}$ This establishes the second part of North's "mercantilist" behavior. Contrary to (33), there is a static welfare gain that is independent of a change in the innovation rate: the last term in (35) captures the positive terms-of-trade effect from increasing the Northern net-of-tariff export price $\lambda /\left(1+\tau_{S}\right)$.

Note the crucial role of the Northern minimum wage rate for our results: since tariff rates affect the steady-state innovation rate only for $w^{\min }>0$, the Northern representative consumer would be indifferent in terms of steady-state utility with respect to $\tau_{N}$ according to (33), but would still prefer $\tau_{S}=\tau_{S}^{\min }$ according to (35), if $w^{\min }=0$ instead. Hence, besides retarding growth and causing unemployment by itself, minimum wages (as well as unemployment benefits unrelated to $w_{L}$, as argued before) have the additional downside that they promote the kind of mercantilist behavior that we regularly observe at WTO trade rounds, and that makes trade agreements so difficult to achieve in practice.

Similarly, Southern per-capita steady-state welfare can be expressed as

$$
F_{S}=\frac{\frac{\imath \log (\lambda)}{\rho}+\left(1-n_{N}\right) \log \left(\frac{c_{S}}{p_{S}^{S}}\right)+n_{N} \log \left(\frac{c_{S}}{p_{N}^{S}}\right)}{\rho}=\frac{\imath \log (\lambda)\left(\frac{1}{\rho}-\frac{1}{l+\mu}\right)+\log \left[\frac{(t+\mu)\left(1+\tau_{S}\right)}{t+\mu\left(1+\tau_{S}\right)}\right]}{\rho},
$$

where we use (16) to substitute for $n_{N}, p_{S}^{S}=1, p_{N}^{S}=\lambda$, and (26) to substitute for $c_{S}$. Obviously, (36) does not directly depend on $\tau_{N}$ but is unambiguously increasing in $l$, hence Southern per-capita steady-state welfare is also maximized for $\tau_{N}=\tau_{N}^{\max }$, where again terms-of-trade considerations do not play a role. A higher $\tau_{N}$ generates effects similar to those observed for $F_{N}$. First, it increases $l$, a dynamic welfare gain.

(29) is taken to substitute for $\imath$ in (34) to check for the corner solution). Since $\imath$ is increasing in $\tau_{N}$, the solution to (32) amounts to maximizing the rate of innovation in the decentralized economy.

${ }^{28}$ Since $\imath^{*}$ is decreasing in $\tau_{S}$, and $u^{*}$ is decreasing in $\imath^{*}$, the effective lower bound $\tau_{S}^{\min }$ for $\tau_{S}$ is where it has increased $\imath^{*}$ to the level $l^{\max }$ that implies $u^{*}=0$ in (27). For the benchmark parameters of our simulation below, we find that $\tau_{s}^{\min }>0$ holds. 
The higher $\imath$ increases $c_{S}$ as seen in equation (26), a static welfare gain. Finally, the higher $\imath$ raises $n_{N}$, a static welfare loss. Maximizing (36) with respect to $\tau_{S}$ yields a long expression of ambiguous sign. ${ }^{29}$ Our numerical analysis reveals, however, that among the feasible set of $\tau_{S}$ that is consistent with $i^{*}>0$ and $1>$ $u^{*} \geq 0$, choosing $\tau_{S}=\tau_{S}^{\min }$ maximizes Southern steady-state welfare for reasonable parameter values. ${ }^{30}$ From this it follows that when starting from $\tau_{S}>\tau_{S}^{\min }$, a steady-state welfare-maximizing Southern government wants to unilaterally liberalize trade in order to benefit from the induced growth push in the North, which more than outweighs the resulting negative terms-of-trade effect.

Overall, terms-of-trade effects play a minor role in determining the net welfare impact of tariff changes for either country, compared to the dynamic effects triggered by a change in the innovation rate: first, for both countries, there is no terms-of-trade effect of a lower $\tau_{N}$ at all. Second, for the North, the positive terms-of-trade effect of a lower $\tau_{S}$ works into the same direction as the positive dynamic welfare effect, and, as obvious from (35), is not even needed to ensure $\partial F_{N} / \partial \tau_{S}<0$, provided that condition (34) is fulfilled. Third, for the South, the negative terms-of-trade effect of a lower $\tau_{S}$ is dominated by the positive welfare effects that follow from a higher Northern innovation rate.

In the following numerical analysis we also show that in a cooperative equilibrium aimed at maximizing global welfare, both countries would agree to choose $\tau_{N}=\tau_{N}^{\max }$ and $\tau_{S}=\tau_{S}^{\min }$. Hence we can establish

Proposition 3: The maximum Northern tariff rate $\tau_{N}^{\max }$ and the minimum Southern tariff rate $\tau_{S}^{\min }$ that are consistent with an interior steady-state equilibrium maximize both Northern and Southern steady-state welfare per capita individually, as well as population-weighted steady-state world welfare.

\footnotetext{
${ }^{29}$ A decrease in $\tau_{S}$ has two effects on Southern welfare: first, it directly reduces $c_{S}$ (negative terms-of-trade effect from increasing the Southern net-of-tariff import price $\left.\lambda /\left(1+\tau_{S}\right)\right)$ which implies a static welfare loss. Second, it raises $\imath$ which, besides causing the usual dynamic welfare gain, triggers two further static welfare effects: a welfare gain by indirectly raising $c_{S}$, and a welfare loss by increasing the share $n_{N}$ of relatively high-priced Northern products in the Southern consumption basket.

${ }^{30}$ This is shown in the Mathematica ${ }^{\odot}$ Appendix to this paper, which is available on the authors' websites (http://cms.uni-konstanz.de/wiwi/grieben/ and http://minerva.union.edu/senerm/).
} 


\subsection{Numerical Simulation of the Steady-State Equilibrium}

The purpose of deriving our steady-state equilibrium also numerically is fourfold: first, we demonstrate that for reasonable parameter values that are consistent with available empirical evidence, a steady-state equilibrium that fulfills all imposed restrictions indeed exists. Second, we verify that condition (34) is clearly satisfied in this equilibrium, thereby supporting our claims on welfare-maximizing tariff choices from the previous section. Third, we demonstrate that not only from a Northern perspective, but also in a cooperative equilibrium aimed at maximizing a population-weighted per-capita world welfare, choosing the highest feasible $\tau_{N}=\tau_{N}^{\max }$ and the lowest feasible $\tau_{S}=\tau_{S}^{\min }$ is optimal. Fourth, we provide a marginal welfare analysis to show that both Northern and Southern per-capita welfare gains from raising $\tau_{N}$ and reducing $\tau_{S}$ are increasing in the level of Northern labor market rigidities, as measured by the levels of $B$, $\alpha$ and $w^{\min }$.

The choice of our benchmark parameter values as shown in Table 1 below is justified as follows: The size of innovations, $\lambda=1.25$, measures the gross mark up (the ratio of the price to the marginal cost) enjoyed by innovators and is estimated as ranging between 1.05 and 1.4 (see Basu 1996 and Norrbin 1993). The subjective discount rate $\rho$ is set at 0.07 to reflect a real interest rate of 7 percent, consistent with the average real return on the US stock market over the past century as calculated by Mehra and Prescott (1985). The world population growth rate $n=0.012$ is calculated as the annual rate of world population growth of middle-income (2008 GNI per capita between $\$ 976$ and \$11,905) and high-income (2008 GNI per capita $\$ 11,906$ or more) countries between 1990 and 2008, as defined by the World Bank (2009). The ratio of Southern to Northern population $\eta_{S}=N_{S} / N_{N}$ is set at 3.93, which is calculated as the ratio of the working age population in middle-income countries to that in high-income countries, again following the World Bank (2009). The choice of the innovation subsidy rate $\sigma_{l}$ at $30 \%$ follows the estimate for the effective US R\&D subsidy rate 1991 reported in Impullitti (2009). The remaining parameters $\left(A_{l}, s_{N}, \alpha, w^{\min }\right.$, $\mu, \tau_{N}, \tau_{S}$, and $\left.B\right)$ are chosen with the objective in mind to generate reasonable values for endogenous variables, in particular to generate a growth rate $g=\imath \log \lambda$ between $0.5 \%$ (following Denison 1985) and $2 \%$ (the average U.S. GDP per capita growth rate from 1950 to 1994 reported in Jones, 2005). The proportion of specialized labor $s_{N}$ is set at 0.002 to generate a wage differential $w_{H} / w_{L}$ that is significantly greater than 1 since it is reasonable to assume that specialized lobbyists are in low supply and earn more than the general-purpose workers. Furthermore, our parameter choices ensure to get a reasonable unemployment rate below $20 \%$, a reasonable industry distribution between the North and the South (i.e. without any region claiming more than $90 \%$ of the industries), and a reasonable union wage premium over the corresponding 
reference wage, $\left(w_{L}-w^{\min }\right) / w^{\min }$ in our model, around 10\% (estimates for this measure range from $6 \%$ for West Germany to 18 percent in US, see Blanchflower and Freeman 1992).

\section{Table 1: Numerical steady-state equilibrium and marginal welfare analysis}

Benchmark parameters: $\lambda=1.25, \rho=0.07, n=0.012, N_{N}=1, N_{S}=3.93, \alpha=0.5, s_{N}=0.002, A_{l}=1, \sigma_{l}=0.3, w^{\min }$ $=1.05, \mu=0.2633, \tau_{N}=\tau_{S}=0.01, B=0.04$

\begin{tabular}{|c|c|c|c|c|c|}
\hline Endogenous variables & $\begin{array}{l}\text { Benchmark } \\
\text { solution }\end{array}$ & $\begin{array}{l}\tau_{N}=\tau_{S}= \\
0.0095\end{array}$ & $\begin{array}{l}B= \\
0.044\end{array}$ & $\begin{array}{l}\alpha= \\
\mathbf{0 . 5 0 2}\end{array}$ & $\begin{array}{l}w^{\min }= \\
1.051\end{array}$ \\
\hline Innovation rate $l$ & 0.07132 & 0.07288 & 0.06820 & 0.06731 & 0.06613 \\
\hline Northern industry share $n_{N}$ & 0.21313 & 0.21678 & 0.20572 & 0.20359 & 0.20075 \\
\hline Bargained wage rate $w_{L}$ & 1.14644 & 1.14666 & 1.14635 & 1.14671 & 1.14679 \\
\hline Relative specialized wage $w_{H} / w_{L}$ & 1.85135 & 1.93314 & 1.69941 & 1.64906 & 1.59201 \\
\hline Union wage premium $\left(w_{L}-w^{\min }\right) / w^{\min }$ & 0.09185 & 0.09206 & 0.09176 & 0.09210 & 0.09114 \\
\hline Unemployment rate $u$ & 0.07510 & 0.05494 & 0.11548 & 0.12698 & 0.14218 \\
\hline $\begin{array}{l}\text { Northern per-capita consumption } \\
\text { expenditure } c_{N}\end{array}$ & 1.06672 & 1.08996 & 1.01998 & 1.00667 & 0.98907 \\
\hline $\begin{array}{l}\text { Southern per-capita consumption } \\
\text { expenditure } c_{S}\end{array}$ & 1.00211 & 1.00204 & 1.00204 & 1.00202 & 1.00199 \\
\hline Share of R\&D in total workforce & 0.07132 & 0.07288 & 0.06820 & 0.06731 & 0.06613 \\
\hline $\begin{array}{l}S_{R \& D} \equiv A_{l} l \\
\text { Share of manufacturing in total workforce } \\
s_{M} \equiv 1-s_{N}-u-s_{R \& D}\end{array}$ & 0.85158 & 0.87019 & 0.81432 & 0.80371 & 0.78969 \\
\hline Utility growth rate $g=\imath \log \lambda$ & 0.01591 & 0.01626 & 0.01522 & 0.01502 & 0.01476 \\
\hline Northern per-capita welfare $F_{N}$ & 3.34894 & 3.72316 & 2.59031 & 2.36896 & 2.07265 \\
\hline Southern per-capita welfare $F_{S}$ & 2.59851 & 2.65685 & 2.47898 & 2.44501 & 2.40017 \\
\hline Northern welfare elasticity $d \log F_{N} / d \log \tau_{N}$ & 0.83831 & 0.71321 & 1.05918 & 1.15284 & 1.31712 \\
\hline Northern welfare elasticity $d \log F_{N} / d \log \tau_{S}$ & -3.07740 & -2.56307 & -4.06548 & -4.48322 & -5.21274 \\
\hline Southern welfare elasticity $d \log F_{S} / d \log \tau_{S}$ & -0.62617 & -0.57779 & -0.64414 & -0.65090 & -0.66392 \\
\hline
\end{tabular}

Notes: Here we provide the main results of our Mathematica ${ }^{\circ}$ Appendix, which is available from the authors' websites. We analyze the variation of only one labor market parameter at a time. The conditions (30), (A.6), (A.7), $1+\tau_{S}<\lambda / w_{L}$ and $1+\tau_{N}<w_{L}$ for the existence of a unique interior steady-state equilibrium are fulfilled throughout, as is also condition (34) for corner solutions in the welfare maximization problems (33) and (35). For the benchmark parameters, it results $l^{\text {comp }}=0.07712, w^{\text {comp }}=1.14576, w^{\max }=1.24288$, and the maximum feasible innovation rate consistent with $u \geq 0$ is $l^{\max }=0.07712$. In general, the benchmark parameters and outcomes are in line with the recent related theoretical growth literature that employ numerical simulations, e.g. Dinopoulos and Segerstrom (1999), Jones (2002), Lundborg and Segerstrom (2002), Sayek and Şener (2006), Şener (2006, 2008), Segerstrom (2007), and Impullitti (2009).

For a wide range of parameters around the benchmark outcome in the first column, condition (34) is clearly fulfilled, hence Northern per-capita welfare is maximized by choosing $\tau_{N}=\tau_{N}^{\max }$ and $\tau_{S}=\tau_{S}^{\min }$. Furthermore, we derived the optimal tariff structure when the aim is to maximize cooperatively a population-weighted world welfare per capita. Consistent with the findings for each individual country, the optimal cooperative solution is again to choose $\tau_{N}=\tau_{N}^{\max }$ and $\tau_{S}=\tau_{S}^{\min }$, as is illustrated in Figure 2 . 


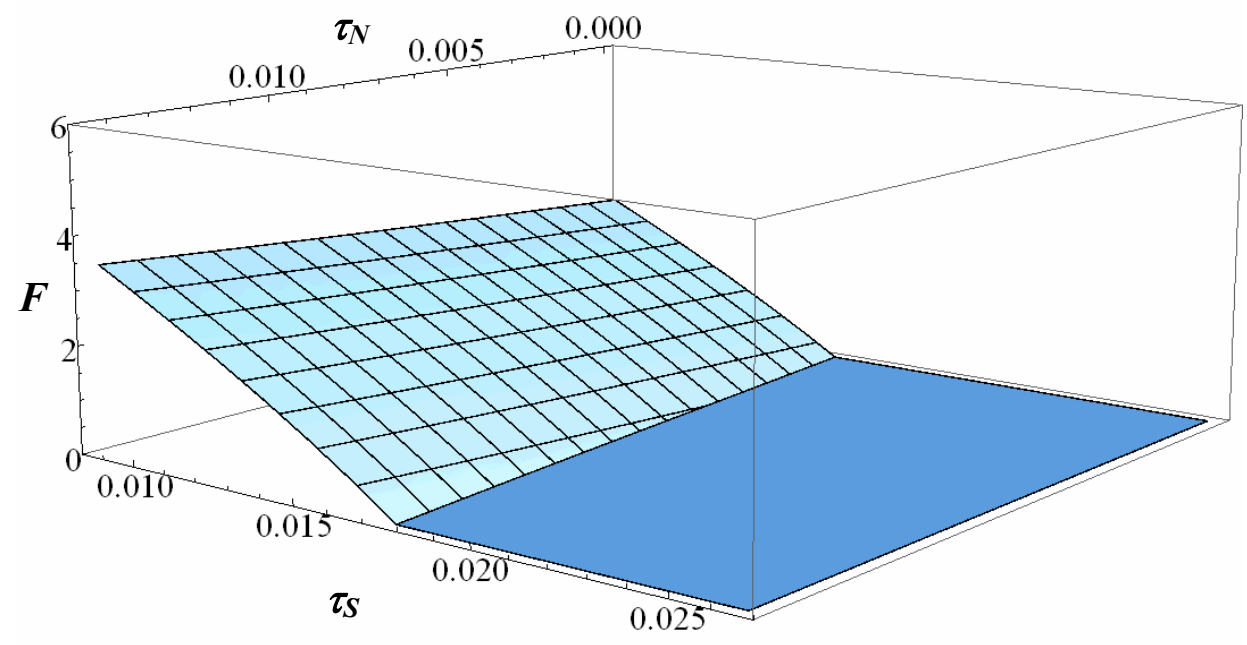

Figure 2: Cooperative maximization of population-weighted world welfare per capita

Parameters: $\lambda=1.25, \rho=0.07, n=0.012, N_{N}=1, N_{S}=3.93, \alpha=0.5, s_{N}=0.002, A_{l}=1, \sigma_{l}=0.3, w^{\min }=1.05$, $\mu=0.2633, B=0.04$. The population-weighted per-capita world welfare is $F \equiv\left[1 /\left(1+\eta_{S}\right)\right] F_{N}+\left[\eta_{S} /\left(1+\eta_{S}\right)\right] F_{S}$. Calculations are from the Mathematica ${ }^{\mathcal{O}}$ Appendix which is available on the authors' websites.

Given the reciprocity principle in actual WTO trade negotiations, such a cooperative outcome will not be feasible in practice. The second column in Table 1 therefore shows the effects of a simultaneous and equi-proportionate cut in both tariff rates. While more rigid Northern labor market institutions analyzed in the other columns force both Northern manufacturing and R\&D workers into unemployment (which reduces $\imath, c_{N}, g, F_{N}$, and $F_{S}$ ), bilateral trade liberalization reallocates unemployed workers into both Northern manufacturing and R\&D employment, which raises $l, c_{N}, g, F_{N}$, and $F_{S}$. Hence for our empirically plausible set of benchmark parameters, symmetric bilateral trade liberalization with equi-proportionate tariff cuts at the margin is clearly preferable to the status quo.

The Northern welfare elasticity with respect to $\tau_{N}, d \log F_{N} / d \log \tau_{N}=\left(d F_{N} / F_{N}\right) /\left(d \tau_{N} / \tau_{N}\right)$, equals 0.8383 in the benchmark case, which implies that for $B=0.04$, a $10 \%$ increase in $\tau_{N}$ (from 0.01 to 0.011 ) would raise Northern per-capita steady-state welfare by $8.38 \%$. As the marginal welfare analysis in Table 1 shows, the Northern welfare elasticities with respect to both $\tau_{N}$ and $\tau_{S}$ are substantially increasing in the levels of Northern labor market rigidities $B, \alpha$, and $w^{\min }$. Moreover, higher Northern rigidities promote 
Southern trade liberalization, since the Southern welfare elasticity with respect to $\tau_{S}, d \log F_{S} / d \log \tau_{S}$, is also increasing in $B, \alpha$, and $w^{\min }$ (all these elasticity results hold for a wider range of rigidities as is shown in the Mathematica ${ }^{(}$Appendix). Hence we can establish

Proposition 4: Starting from a unique steady-state equilibrium with an interior solution and sufficiently low tariff rates, the Northern steady-state per-capita welfare gains of Northern protectionism $\left(\tau_{N} \uparrow\right)$ and both the Northern and Southern steady-state per-capita welfare gains from Southern trade liberalization $\left(\tau_{S} \downarrow\right)$ are increasing in the level of Northern labor market rigidities $B, \alpha$, and $w^{\min }$.

In other words, Northern mercantilist behavior is more pronounced when the Northern labor market is more rigid. We finally note another advantage of bilateral trade liberalization: after the simultaneous decrease in tariffs, Northern incentives for protectionism, as measured by $d \log F_{N} / d \log \tau_{N}$, decline.

\section{Comparison with Related Literature}

\subsection{Explaining Mercantilism}

Krugman (1997) characterizes the GATT negotiations as reflecting mercantilist behavior that cannot be justified by any economic reasoning. He claims that, when neglecting the optimal-tariff argument that has little relevance in reality, "The economist's case for free trade is essentially a unilateral case: a country serves its own interests by pursuing free trade regardless of what other countries may do" (p. 113). Our analysis casts doubt on the validity of Krugman's claim by considering the effects of labor market rigidities. $^{31}$

Bagwell and Staiger (1999), by contrast, defend the principle of reciprocity that is typically applied in GATT or WTO trade rounds as leading to welfare improvements for the economies of all negotiating governments. This is because "[...] a unilateral liberalization effort is unappealing [...] as a consequence of the associated deterioration in the terms of trade", while "a negotiated mutual reduction in tariffs that conforms to the principle of reciprocity results in a higher trade volume without a terms-of-trade loss for either government" (p. 226). ${ }^{32}$

${ }^{31}$ Labor market imperfections are actually not a necessary condition to counter Krugman's claim: in our companion paper Grieben and Şener (2009) we show that even with perfectly flexible labor markets, unilateral Southern trade liberalization reduces Northern innovative activity and the worldwide steady-state growth rate in an asymmetric setting where product-cycle and interindustry trade coexist.

${ }^{32}$ In Appendix R.4 (which is available upon request) we demonstrate that the total trade volume is increasing in $t$, 
Observe that terms-of-trade effects (only for changes in $\tau_{S}$ ) and trade-volume effects (of ambiguous sign) are embodied but largely irrelevant in our welfare analysis in section 2.11. Instead, dynamic effects that work through changes in the innovation rate $t$ are driving the welfare results. These dynamic welfare effects are completely outside the scope of Bagwell and Staiger (1999).

Ethier $(2004,2007)$ offers a critique on Bagwell and Staiger's "Received Theory" of explaining the reciprocity principle in trade negotiations solely by focusing on terms-of-trade externalities. Ethier (2007) argues that the "Received Theory" is dramatically inconsistent with empirical evidence of actual multilateral trade agreements: “[...] For over four decades, successive GATT rounds have produced trade agreements that do not prevent terms-of-trade manipulation while trade theorists have produced theories of trade agreements in which such prevention is the sole object" (p. 606). Ethier (2007, section 8) proposes a political-economy theory that is based on the protection-for-sale model of Grossman and Helpman (1994) of trade agreements, where terms-of-trade issues are completely out of the picture. Only political-economy considerations remain to bring theory in line with empirical evidence again, namely to explain that, first, export taxes are not observed although trade negotiations would allow to use them, and second, that we observe countervailing-duty laws being implemented. However, Ethier (2007, p. 621) also challenges the existing empirical evidence for the protection-for-sale model. Our paper offers an alternative explanation for the apparent mercantilism in trade negotiations that does also not rely on terms-of-trade effects but instead emphasizes the growth-promoting effects of Northern tariffs when there are union wage bargaining and a minimum wage rate in the North. Moreover, as argued earlier, in the framework of this paper, the Northern government has no incentive to set export taxes but a strong incentive to react by means of countervailing-duty laws to any Southern export subsidies. All this is consistent with the empirical evidence emphasized by Ethier $(2004,2007)$.

\subsection{Interactions Between Trade and Labor Market Policies}

Our model captures the substitutability between Northern labor market and trade policies. For example, in Northern countries with rigid labor markets, there may be pressure to use protectionism (increase in $\tau_{N}$ ) to unwind the negative welfare effects of higher minimum wages or vice versa. This is in line with the theoretical findings of Costinot (2009) who analyzes a small open economy with search frictions, where a welfare-maximizing government chooses optimal trade taxes across industries. He concludes that "In $a$

whereas for a given level of $l$ it moves in an ambiguous direction with changes in $\tau_{S}$ and remains neutral to changes in $\tau_{N}$. We show that unilateral Northern trade liberalization unambiguously reduces the total trade volume while unilateral Southern trade liberalization has an ambiguous effect on it, and thus bilateral trade liberalization by equal proportions, i.e. $d \tau_{N}=d \tau_{S}=d \tau<0$, has also an ambiguous net effect on the total trade volume. 
cross-section of industries, parameters which are positively correlated with unemployment - workers' bargaining power [...] - should also be positively correlated with trade taxes" (p. 1013). This is also confirmed by empirical evidence of Matschke and Sherlund (2006) who find a positive correlation between unionization rates and trade taxes across industries. Our model shows that these results also apply for the aggregate Northern economy in a two-country North-South framework.

\subsection{Growth Impact of Stronger Labor Unions}

The negative growth impact of stronger labor unions in our model contrasts sharply with the findings of Palokangas (1996) and Lingens (2003). In a first-generation endogenous growth setting which still features the counterfactual scale effect, they distinguish between high-skilled and low-skilled workers, and innovative $\mathrm{R} \& \mathrm{D}$ is only done by the former. Only the low-skilled wage rate is bargained above the competitive level. Competition on product markets is such that if the labor union is able to bargain a higher low-skilled wage rate, this increase in production costs is passed on to consumer prices. This reduces consumption demand and hence necessarily reduces unskilled employment. Given the additional assumption that high-skilled and low-skilled workers are weakly substitutable (i.e., complements) in manufacturing, this reduces the productivity of high-skilled workers in manufacturing, decreases their competitive wage rate, and hence reduces marginal R\&D costs. Consequently, some high-skilled workers are reallocated towards R\&D which finally raises economic growth.

Our paper differs in all these respects. We assume homogenous labor for production and R\&D activities (hence the degree of substitutability is not an issue) and derive a unique bargained wage rate for those workers. Moreover, product prices are pinned down in terms of the Southern wage rate. Under the Nash equilibrium of the Bertrand pricing game, Northern firms engage in limit pricing and charge a mark up over the marginal cost of the Southern follower firms. In essence, our modeling captures the relevance of the South in determining manufactured goods prices by explicitly incorporating the threat of competition coming from the South. This renders Northern product prices independent of the Northern bargained wage rate and thereby mutes the direct negative employment effect of a stronger union through product prices. Instead, our model offers an indirect negative employment effect that works through a reduction of Northern innovation activity, which reduces demand for both $R \& D$ and manufacturing labor, as a lower innovation rate reduces the proportion of Northern manufacturing industries in the global economy. Finally, we derive our results in a fully-endogenous growth model without scale effects taking seriously the Jones (1995a, b) critique. 


\section{Conclusions}

We have analyzed the long-run economic growth and welfare consequences of various globalization forces in a scale-free North-South endogenous growth model with union wage bargaining in the North. We find that Southern unilateral trade liberalization raises Northern firms' profits by more than it increases the bargained wage rate. This raises the Northern innovation rate and implies a permanent increase in product quality growth for both countries. In steady-state welfare simulations, we find that the dynamic gains triggered by faster Northern innovation play a dominant role and determine the net change in welfare in the presence of other static welfare effects. Consequently, the higher Northern innovation rate boosts the steady-state welfare of both countries. By contrast, Northern unilateral trade liberalization reduces Northern firms' profits by more than it reduces the bargained wage rate. This reduces the innovation rate and thus the steady-state welfare levels for both countries, while raising Northern unemployment. Thus, our North-South model with an asymmetric labor market structure suggests that at the WTO meetings, Northern countries with unionized labor markets would optimally pursue mercantilist behavior whereas Southern countries with flexible labor markets would optimally pursue trade liberalization. We reach these results without relying on terms-of-trade arguments, which is in line with Ethier's $(2004,2007)$ critique of the "Received Theory" of trade negotiations as exemplified by Bagwell and Staiger (1999).

Northern labor market rigidities are shown to be harmful on two grounds. First, a stronger labor union, a higher minimum wage and higher shutting-down costs for Northern firms have direct adverse effects by reducing worldwide growth and welfare, and increasing Northern unemployment. Second, the Northern incentives for protectionism (as measured by the Northern welfare elasticity with respect to changes in the Northern import tariff) are increasing in the level of Northern labor market rigidities. This is an obstacle for reaching a trade agreement at WTO negotiations where the reciprocity principle applies. Since we demonstrate numerically that bilateral trade liberalization at the margin raises worldwide growth and welfare and hence is clearly preferable to the status quo, Northern labor market rigidities are also indirectly harmful by handicapping welfare-increasing bilateral trade agreements at the margin. We are keen to point out that our findings do not advocate protectionism by advanced countries with labor market rigidities. If a normative conclusion is to be drawn from this paper, it should rather be to reduce labor market rigidities.

Further related research can complement our analysis on two grounds. First, from a theoretical perspective, one can incorporate FDI and outsourcing into the model and investigate the effects of globalization that materialize through these channels. Second, from an empirical perspective, one can test our result of an inverse relationship between labor market flexibility and protectionist attitudes. This requires finding 
a reasonable proxy for the protectionist attitude of governments. Kee et al. (2009)'s trade restrictiveness indicators could provide such measures. Such an empirical study can also complement Dutt et al. (2009), who find a positive relationship between protection and unemployment using a model that focuses on the static effects of trade liberalization in a standard Ricardian framework with frictional labor markets.

\section{Appendices}

\section{Appendix A: Comparative Statics}

To apply the implicit function theorem, we rewrite (29) as

$$
f\left(\imath^{*}, w^{\min }, \ldots\right)=\frac{\eta_{S}(\imath+\mu)}{\mu \lambda}\left\{\frac{1}{\alpha+(1-\alpha) w^{\min } \cdot \frac{\imath+\mu\left(1+\tau_{S}\right)}{\lambda\left[\imath\left(1+\tau_{N}\right)+\mu\right]}}-1\right\}-\left(1-\sigma_{\imath}\right) A_{\iota}[\rho+(1+B)(2 \imath+\mu)-n]=0 .
$$

We then derive, after collecting terms,

$$
\frac{\partial \iota^{*}}{\partial w^{\min }}=-\frac{\partial f(\cdot) / \partial w^{\min }}{\partial f(\cdot) / \partial \iota^{*}}=\frac{\frac{(t+\mu)(1-\alpha)\left[\imath+\mu\left(1+\tau_{S}\right)\right]}{\lambda\left[\imath\left(1+\tau_{N}\right)+\mu\right]}}{C^{2}\left[A-\frac{\mu \lambda\left(1-\sigma_{t}\right) A_{t} 2(1+B)}{\eta_{S}}\right]+\frac{(\imath+\mu)(1-\alpha) w^{\min } \mu\left[\tau_{N}+\tau_{S}\left(1+\tau_{N}\right)\right]}{\lambda\left[\imath\left(1+\tau_{N}\right)+\mu\right]^{2}}},
$$

where

$$
C \equiv \alpha+(1-\alpha) \frac{w^{\min }}{w^{\max }}<1, \quad A \equiv \frac{1}{C}-1>0
$$

The numerator of (A.2) is positive, and the second term in the denominator converges to zero when tariffs go to zero. Therefore, $\partial \imath^{*} / \partial w^{\min }<0$ follows for sufficiently low tariff rates if the first term in the denominator of (A.2) is negative. Using (A.1) and $\tau_{N}=\tau_{S}=0$ in $A$, this condition can be written as

$$
\frac{\mu \lambda\left(1-\sigma_{t}\right) A_{t}[\rho+(1+B)(2 \imath+\mu)-n]}{\eta_{S}(\imath+\mu)}<\frac{\mu \lambda\left(1-\sigma_{t}\right) A_{t} 2(1+B)}{\eta_{S}},
$$

which reduces to condition (30) in the main text. Under the same assumptions, it is

$$
\frac{\partial \iota^{*}}{\partial \tau_{N}}=-\frac{\partial f(\cdot) / \partial \tau_{N}}{\partial f(\cdot) / \partial \iota^{*}}=\frac{\frac{(l+\mu)(1-\alpha) w^{\min }{ }\left[\imath+\mu\left(1+\tau_{S}\right)\right]}{\lambda\left[\imath\left(1+\tau_{N}\right)+\mu\right]^{2}}}{C^{2}\left[A-\frac{\mu \lambda\left(1-\sigma_{t}\right) A_{t} 2(1+B)}{\eta_{S}}\right]+\frac{(l+\mu)(1-\alpha) w^{\min } \mu\left[\tau_{N}+\tau_{S}\left(1+\tau_{N}\right)\right]}{\lambda\left[\imath\left(1+\tau_{N}\right)+\mu\right]^{2}}}>0,
$$




$$
\frac{\partial \iota^{*}}{\partial \tau_{S}}=-\frac{\partial f(\cdot) / \partial \tau_{S}}{\partial f(\cdot) / \partial \iota^{*}}=\frac{\frac{-(l+\mu)(1-\alpha) w^{\min } \mu}{\lambda\left[\iota\left(1+\tau_{N}\right)+\mu\right]}}{C^{2}\left[A-\frac{\mu \lambda\left(1-\sigma_{t}\right) A_{t} 2(1+B)}{\eta_{S}}\right]+\frac{(l+\mu)(1-\alpha) w^{\min } \mu\left[\tau_{N}+\tau_{S}\left(1+\tau_{N}\right)\right]}{\lambda\left[\imath\left(1+\tau_{N}\right)+\mu\right]^{2}}}<0 .
$$

For $\tau_{N}=\tau_{S}=0,(29)$ can be solved explicitly for

$$
\left.\imath^{*}\right|_{\tau_{N}=\tau_{S}=0}=\frac{\eta_{S}(1-\alpha)\left(1-\frac{w^{\min }}{\lambda}\right)-\left[\alpha \lambda+(1-\alpha) w^{\min }\right][\rho+(1+B) \mu-n]\left(1-\sigma_{\imath}\right) A_{\iota}}{2(1+B)\left(1-\sigma_{\imath}\right) A_{\imath}\left[\alpha \lambda+(1-\alpha) w^{\min }\right]-\frac{\eta_{S}(1-\alpha)\left(1-\frac{w^{\min }}{\lambda}\right)}{\mu}},
$$

and all other comparative-static results of (29) are straightforward from this. ${ }^{33}$ Note that for ${ }^{*}>0$, both numerator and denominator of (A.5) must be positive. ${ }^{34}$ They cannot be both negative since this would imply

$$
\begin{aligned}
& 2 \mu(1+B)\left(1-\sigma_{\iota}\right) A_{\iota}\left[\alpha \lambda+(1-\alpha) w^{\min }\right]<\eta_{S}(1-\alpha)\left(1-\frac{w^{\min }}{\lambda}\right) \\
& <\left(1-\sigma_{\imath}\right) A_{\iota}\left[\alpha \lambda+(1-\alpha) w^{\min }\right][\rho-n+(1+B) \mu] \Leftrightarrow 2 \mu(1+B)<\rho-n+(1+B) \mu,
\end{aligned}
$$

which is a contradiction to (30). Hence, condition (30) is also required under free trade to ensure $l^{*}>0$. The condition that the numerator of (A.5) must be positive is equivalent to

$$
\frac{\frac{\eta_{S}}{\lambda}\left[\frac{\lambda}{\alpha \lambda+(1-\alpha) w^{\min }}-1\right]}{\rho+(1+B) \mu-n}>\left(1-\sigma_{t}\right) A_{t}
$$

where the LHS of (A.6) is the discounted R\&D benefit for $\tau_{N}=\tau_{S}=0$ and $\imath \rightarrow 0$ from the FEIN condition (29). This ensures a positive innovation rate under the actual discount rate $\rho+(1+B)(2 \imath+\mu)-n$ for $\operatorname{R} \& \mathrm{D}$

\footnotetext{
${ }^{33}$ The steady-state innovation rate $\imath^{*}$ also depends negatively on the interest (households' time preference) rate $\rho$ and the unit resource requirement for R\&D $A_{t} \equiv a_{t} \delta s_{N} /(n \gamma)$; it depends positively on the population growth rate $n$ and the R\&D subsidy rate $\sigma_{l}$, while the net impact of a change in $\lambda$ on $\imath^{*}$ is ambiguous.

${ }^{34}$ Since $A_{l} \rightarrow \infty$ for $n \rightarrow 0$, dividing both numerator and denominator of (A.5) by $A_{l}$ and then setting $n=0$ shows immediately that a positive steady-state innovation rate is not defined for zero population growth. In our model, RPAs lead to accumulation of R\&D difficulty stock over time. Thus, supporting a constant and positive innovation rate requires expanding resources for $\mathrm{R} \& \mathrm{D}$, which in turn requires positive population growth. However, if we introduce a constant depreciation rate $\sigma>0$ for R\&D difficulty, a positive steady-state innovation rate would no longer require positive population growth $n>0$. In this case, the equation of motion for R\&D difficulty will be $\dot{D}=n_{N} \delta X-\sigma D$ instead of (8). With $n=0$, setting $\dot{D}=0$ would imply $D=s_{N} N_{N} \delta /(\sigma \gamma)$, a constant R\&D difficulty and positive steady-state growth. This result is in line with Dinopoulos and Syropoulos (2007), where RPAs are instead modeled as a flow variable. However, it contrasts with the general class of semi-endogenous growth models discussed in Jones (2005, p. 1073), where R\&D difficulty is linked exogenously to innovation and growth comes to a halt with zero population growth.
} 
benefits. The condition that the denominator of (A.5) must be positive is equivalent to

$$
\frac{\frac{\eta_{S}}{\lambda}\left[\frac{\lambda}{\alpha \lambda+(1-\alpha) w^{\min }}-1\right]}{2(1+B) \mu}<\left(1-\sigma_{\iota}\right) A_{t} .
$$

Hence for existence and uniqueness of our steady-state equilibrium, we need (30), (A.6) and (A.7) to be fulfilled.

\section{Appendix B: Steady-State Equilibrium with Competitive Wage Rate}

We can derive the competitive wage rate as a function solely in $l$, that is, the level of $w_{L}$ that would prevail

if $w^{\min }<w^{\text {comp }}$ and if there were no Northern wage bargaining. From (11), it is $w_{L}=v_{N} /\left[\left(1-\sigma_{l}\right) a_{l} D\right]$. Using (15) together with $r=\rho$ and $\dot{v}_{N} / v_{N}=n$ to substitute for $v_{N},(9)$ and (19) to substitute for $D,(17)$ to substitute for $c_{S}$, (25) to substitute for $c_{N}$, simplifying and solving this free-entry in innovation (FEIN) condition for $w^{\text {comp }}$ yields

$$
\begin{aligned}
w^{\text {comp }} & =\frac{\lambda\left[\imath\left(1+\tau_{N}\right)+\mu\right] \eta_{S}(l+\mu)}{\left[\imath+\mu\left(1+\tau_{S}\right)\right]\left\{\eta_{S}(l+\mu)+\mu \lambda[\rho+(1+B)(2 \imath+\mu)-n]\left(1-\sigma_{\imath}\right) A_{\imath}\right\}} \\
& \Leftrightarrow \frac{w^{c o m p}}{w^{\max }}=\frac{1}{1+\frac{\mu \lambda[\rho+(1+B)(2 t+\mu)-n]\left(1-\sigma_{t}\right) A_{t}}{\eta_{S}(l+\mu)}},
\end{aligned}
$$

where $w^{\max }$ is given as before in (24). If the competitive wage rate applies, the Northern labor markets must clear, so that the steady-state innovation rate corresponding to that situation can be derived from setting $u^{*}=0$ in (27):

$$
\imath^{c o m p}=\frac{1-s_{N}}{\frac{\eta_{S}}{\lambda \mu}+A_{\imath}} .
$$

Note that if follows from (B.2) that our model turns into a semi-endogenous growth framework for competitive wage setting: $l^{\text {comp }}$ cannot be influenced by any public policies as long as Southern imitation remains exogenous. The interpretation of $l^{\text {comp }}$ is straightforward: it increases for a lower share $s_{N}$ of specialized workers engaged in rent protection, a lower share of general-purpose workers employed in manufacturing (which is positively related to $\eta_{S} /(\lambda \mu)$ ), and a lower effective unit resource requirement for $\operatorname{R} \& \mathrm{D} A_{l}$. Note in particular that as in the baseline setting of Grieben and Şener (2009), tariffs are neutral for the steady-state innovation rate under competitive wage determination. Any profit-increasing tariff changes (i.e. an increase in $\tau_{N}$ that raises the profits from Northern domestic sales, or a decrease in $\tau_{S}$ that raises the 
profits from Northern exports) are mitigated by a corresponding increase in $w^{\text {comp }}$, and the resulting general-equilibrium effects associated with changes in $w^{\operatorname{comp}}, c_{N}$, and $c_{S}$ completely nullify the initial positive tariff stimulus, and similarly for profit-decreasing tariff changes. We note that $\rho, n, B$, and $\sigma_{\iota}$ do not affect $i^{\text {comp }}$ either. Hence, a similar nullification effect is at work regarding these parameters.

Finally, it follows from (27) and (B.2) that the equilibrium innovation rate ${ }^{*}$ falls short of the innovation rate under competitive wage setting $l^{\text {comp }}$ whenever there is positive unemployment:

$$
\frac{u^{*}}{\frac{\eta_{S}}{\lambda \mu}+A_{t}}=t^{\text {comp }}-\imath^{*} \text {. }
$$

This is the case whenever $w_{L}>w^{\text {comp }}$.

\section{Literature}

Alessandria, George and Delacroix, Alain (2008): "Trade and the (Dis)Incentive to Reform Labor Markets: The Case of Reform in the European Union". Journal of International Economics, Vol. 75(1), 151-166.

Andersen, Torben M. (2005): "Product Market Integration, Wage Dispersion and Unemployment". Labour Economics, Vol. 12(3), 379-406.

Andersen, Torben M. and Skaksen, Jan Rose (2007): "Labour Demand, Wage Mark-ups and Product Market Integration". Journal of Economics, Vol. 92(2), 103-135.

Arnold, Lutz G. (2002): "On the Growth-Effects of North-South Trade: the Role of Labor Market Flexibility". Journal of International Economics, Vol. 58(2), 451-466.

Bagwell, Kyle and Staiger, Robert W. (1999): "An Economic Theory of GATT". American Economic Review, Vol. 89(1), 215-248.

Basu, Susanto (1996): “Procyclical Productivity: Increasing Returns or Cyclical Utilization?”, Quarterly Journal of Economics, Vol. 111(3), 719-51.

Binmore, Ken; Rubinstein, Ariel and Wolinsky, Asher (1986): "The Nash Bargaining Solution in Economic Modelling”. Rand Journal of Economics, Vol. 17(2), 176-188.

Blanchflower, David G. and Freeman, Richard B. (1992): "Unionism in United States and Other Advanced OECD Countries". Industrial Relations, Vol. 31(1), 56-79.

Cahuc, Pierre and Zylberberg, André (2004): Labor Economics, MIT Press.

Costinot, Arnaud (2009): “Jobs, Jobs, Jobs: A 'New' Perspective on Protectionism”. Journal of the European Economic Association, Vol. 7(5), 1011-1041.

Davis, Donald R. (1998a): "Does European Unemployment Prop Up American Wages? National Labor Markets and Global Trade". American Economic Review, Vol. 88(3), 478-494.

Davis, Donald R. (1998b): "Technology, Unemployment, and Relative Wages in a Global Economy". European Economic Review, Vol. 42(9), 1613-1633.

Denison, Edward F. (1985): Trends in American Economic Growth, 1929-1982. The Brookings Institution, Washington, DC.

Dinopoulos, Elias and Segerstrom, Paul S. (1999): “A Schumpeterian Model of Protection and Relative 
Wages". American Economic Review, Vol. 89(3), 450-472.

Dinopoulos, Elias and Segerstrom, Paul S. (2007): North-South Trade and Economic Growth. Manuscript, University of Florida and Stockholm School of Economics.

Dinopoulos, Elias and Syropoulos, Constantinos (2007): "Rent Protection as a Barrier to Innovation and Growth". Economic Theory, Vol. 32(2), 309-332.

Driffill, John and van der Ploeg, Frederick (1995): "Trade Liberalization With Imperfect Competition in Goods and Labour Markets". Scandinavian Journal of Economics, Vol. 97(2), 223-243.

Dutt, Pushan; Mitra, Devashish and Ranjan, Priya (2009): "International Trade and Unemployment: Theory and Cross-National Evidence". Journal of International Economics, Vol. 78(1), 32-44.

Eckel, Carsten and Egger, Hartmut (2009): "Wage Bargaining and Multinational Firms". Journal of International Economics, Vol. 77(2), 206-214.

Egger, Hartmut and Egger, Peter (2003): "Outsourcing and Skill-specific Employment in a Small Economy: Austria After the Fall of the Iron Curtain". Oxford Economic Papers, Vol. 55(4), 625-643.

Ethier, Wilfred J. (2004): "Political Externalities, Nondiscrimination, and a Multilateral World". Review of International Economics, Vol. 12(3), 303-320.

Ethier, Wilfred J. (2005): "Globalization, Globalization: Trade, Technology and Wages". International Review of Economics and Finance, Vol. 14(3), 237-258.

Ethier, Wilfred J. (2007): "The Theory of Trade Policy and Trade Agreements: A Critique". European Journal of Political Economy, Vol. 23(3), 605-623.

Gaston, Noel (2002): "The Effects of Globalisation on Unions and the Nature of Collective Bargaining". Journal of Economic Integration, Vol. 17(2), 377-396.

Glass, Amy Jocelyn (2004): "Outsourcing under Imperfect Protection of Intellectual Property". Review of International Economics, Vol. 12(5), 867-884.

Grieben, Wolf-Heimo (2004): "Schumpeterian Growth, North-South Trade and Wage Rigidity". Contributions to Macroeconomics, Vol. 4(1), Article 9.

Grieben, Wolf-Heimo (2005): "A Schumpeterian North-South Growth Model of Trade and Wage Inequality”. Review of International Economics, Vol. 13(1), 106-128.

Grieben, Wolf-Heimo (2009): "Can Countries With Severe Labor Market Frictions Gain From Globalization?". Review of Development Economics, Vol. 13(2), 230-247.

Grieben, Wolf-Heimo and Şener, Fuat (2009): "Globalization, Rent Protection Institutions, and Going Alone In Freeing Trade”. European Economic Review, Vol. 53(8), 1042-1065.

Grossman, Gene and Helpman, Elhanan (1994): "Protection For Sale". American Economic Review, Vol. 89(4), 833-850.

Gustafsson, Peter and Segerstrom, Paul S. (2009): "North-South Trade With Increasing Product Variety". Journal of Development Economics, in press, doi:10.1016/j.jdeveco.2009.02.005.

Hall, Robert E. and Milgrom, Paul R. (2008): “The Limited Influence of Unemployment on the Wage Bargain”. American Economic Review, Vol. 98(4), 1653-1674.

Helpman, Elhanan and Itskhoki, Oleg (2009): "Labor Market Rigidities, Trade and Unemployment". Review of Economic Studies, forthcoming.

Huizinga, Harry (1993): "International Market Integration and Union Wage Bargaining". Scandinavian Journal of Economics, Vol. 95(2), 249-255.

ILO (2008): Global Wage Report 2008/09. Minimum Wages and Collective Bargaining: Towards Policy Coherence, Geneva.

Impullitti, Giammario (2009): "International Competition and U.S. R\&D Subsidies: A Quantitative Wel- 
fare Analysis". International Economic Review, forthcoming.

Jones, Charles I. (1995a): “Time Series Tests of Endogenous Growth Models". Quarterly Journal of Economics, Vol. 110(2), 495-525.

Jones, Charles I. (1995b): "R\&D-Based Models of Economic Growth". Journal of Political Economy, Vol. 103(4), 759-784.

Jones, Charles I. (2002): "Sources of US Economic Growth in a World of Ideas". American Economic Review, Vol. 92(1), 220-39.

Jones, Charles I. (2005): "Growth and Ideas". Chapter 16 in Aghion, P. and Durlauf, S.N. (eds.), Handbook of Economic Growth, Vol. 1b, North-Holland, Amsterdam, 1063-1111.

Kee, Hiau Looi; Nicita, Alessandro and Olarreaga, Marcelo (2009): "Estimating Trade Restrictiveness Indices". Economic Journal, Vol. 119(January), 172-199.

Krugman, Paul (1997): “What Should Trade Negotiators Negotiate About?”. Journal of Economic Literature, Vol. 35(1), 113-120.

Layard, Richard; Nickell, Stephen and Jackman, Richard (2005): Unemployment: Macroeconomic Performance and the Labour Market, $2^{\text {nd }}$ ed., Oxford University Press.

Lingens, Jörg (2003): "The Impact of a Unionised Labour Market in a Schumpeterian Growth Model". Labour Economics, Vol. 10(1), 91-104.

Lommerud, Kjell Erik; Meland, Frode and Straume, Odd Rune (2009): “Can Deunionization Lead to International Outsourcing?". Journal of International Economics, Vol. 77(1), 109-119.

Lu, Chia-Hui (2007): "Moving Up or Moving Out? A Unified Theory of R\&D, FDI, and Trade". Journal of International Economics, Vol. 71(2), 324-343.

Lundborg, Per and Segerstrom, Paul S. (2002): "The Growth and Welfare Effects of International Mass Migration". Journal of International Economics, Vol. 56(1), 177-204.

Matschke, Xenia and Sherlund, Shane M. (2006): "Do Labor Issues Matter in the Determination of U.S. Trade Policy? An Empirical Reevaluation”. American Economic Review, Vol. 96(1), 405-421.

Meckl, Jürgen (2006): "Does European Unemployment Prop Up American Wages? National Labor Markets and Global Trade: Comment". American Economic Review, Vol. 96(5), 1924-1930.

Mehra, Rajnish and Prescott, Edward C. (1985): "The Equity Premium: A Puzzle". Journal of Monetary Economics, Vol. 15(2), 145-161.

Mezzetti, Claudio and Dinopoulos, Elias (1991): "Domestic Unionization and Import Competition". Journal of International Economics, Vol. 31(1-2), 79-100.

Moore, Mark P. and Ranjan, Prija (2005): "Globalisation vs Skill-Biased Technological Change: Implications for Unemployment and Wage Inequality”. Economic Journal, Vol. 115(April), 391-422.

Naylor, Robin (1998): "International Trade and Economic Integration When Labour Markets are Generally Unionised". European Economic Review, Vol. 42(7), 1251-1267.

Naylor, Robin (1999): "Union Wage Strategies and International Trade". Economic Journal, Vol. 109(January), 102-125.

Nickell, Steven (2003): "Labor Market Institutions and Unemployment in OECD Countries". CESifo DICE Report, Vol. 1(2), 13-26.

Nickell, Steven; Nunziata, Luca, and Ochel, Wolfgang (2005): "Unemployment in the OECD since the 1960s. What Do We Know?”. Economic Journal, Vol. 115(January), 1-27.

Norrbin, Stefan C. (1993): "The Relationship between Price and Marginal Cost in US Industry: a Contradiction". Journal of Political Economy, Vol. 101(6): 1149-1164.

Ortigueira, Salvador (2008): "Technical Progress and the Evolution of Wage-Bargaining Arrangements", 
in Neumaier, O.; Schweiger, G. and Sedmak, C. (eds.), Perspectives on Work, Wien-Münster: LitVerlag, 111-120.

Palokangas, Tapio (1996): "Endogenous Growth and Collective Bargaining". Journal of Economic Dynamics and Control, Vol. 20(5), 925-944.

Palokangas, Tapio (2004): “Union-Firm Bargaining, Productivity Improvement and Endogenous Growth". Labour, Vol. 18(2), 191-205.

Palokangas, Tapio (2005): "International Labor Union Policy and Growth with Creative Destruction". Review of International Economics, Vol. 13(1), 90-105.

Rodrik, Dani (1994): "The Rush to Free Trade in the Developing World: Why So Late? Why Now? Will It Last?". In: Haggard, S. and Webb, S. (Eds.), Voting for Reform: Democracy, Political Liberalization, and Economic Adjustment, Oxford University Press, New York, pp. 61-88.

Segerstrom, Paul S. (2007): “Intel Economics”. International Economic Review, Vol. 48(1), 247-280.

Sayek, Selin and Şener, Fuat (2006). "Outsourcing and Wage Inequality in a Dynamic Product Cycle Model." Review of Development Economics, Vol. 10(1), 1-19.

Şener, Fuat (2001): "Schumpeterian Unemployment, Trade and Wages". Journal of International Economics, Vol. 54(1), 119-148.

Şener, Fuat (2006): "Labor Market Rigidities and R\&D-based Growth in the Global Economy". Journal of Economic Dynamics \& Control, Vol. 30(5), 769-805.

Şener, Fuat (2008): "R\&D Policies, Endogenous Growth and Scale Effects". Journal of Economic Dynamics \& Control, Vol. 32(12), 3895-3916.

Şener, Fuat and Zhao, Laixun (2009): "Globalization, R\&D and the iPod Cycle". Journal of International Economics, Vol. 77(1), 101-108.

Skaksen, Jan Rose (2004): "International Outsourcing When Labour Markets are Unionized". Canadian Journal of Economics, Vol. 37(1), 78-94.

Skaksen, Mette Yde and Sørensen, Jan Rose (2001): "Should Labor Unions Appreciate Foreign Direct Investment”. Journal of International Economics, Vol. 55(2), 379-390.

Tang, Linghui (2006): "Communication Costs and Trade of Differentiated Goods". Review of International Economics, Vol. 14(1), 54-68.

Wacziarg, R. and Welch, K. H. (2008): “Trade Liberalization and Growth: New Evidence”. World Bank Economic Review, Vol. 22(2), 187-231.

World Bank (2009): World Development Indicators, Washington, DC.

Zhao, Laixun (1995): “Cross-hauling Direct Foreign Investment and Unionized Oligopoly". European Economic Review, Vol. 39(6), 1237-1253.

Zhao, Laixun (1998): “The Impact of Foreign Direct Investment on Wages and Employment". Oxford Economic Papers, Vol. 50(2), 284-301.

Zhao, Laixun (2001): "Unionization, Vertical Markets, and the Outsourcing of Multinationals". Journal of International Economics, Vol. 55(1), 187-202. 


\section{CESifo Working Paper Series}

for full list see www.cesifo-group.org/wp

(address: Poschingerstr. 5, 81679 Munich, Germany, office@cesifo.de)

2829 Rainald Borck and Martin Wimbersky, Political Economics of Higher Education Finance, October 2009

2830 Torfinn Harding and Frederick van der Ploeg, Is Norway's Bird-in-Hand Stabilization Fund Prudent Enough? Fiscal Reactions to Hydrocarbon Windfalls and Graying Populations, October 2009

2831 Klaus Wälde, Production Technologies in Stochastic Continuous Time Models, October 2009

2832 Biswa Bhattacharyay, Dennis Dlugosch, Benedikt Kolb, Kajal Lahiri, Irshat Mukhametov and Gernot Nerb, Early Warning System for Economic and Financial Risks in Kazakhstan, October 2009

2833 Jean-Claude Trichet, The ECB's Enhanced Credit Support, October 2009

2834 Hans Gersbach, Campaigns, Political Mobility, and Communication, October 2009

2835 Ansgar Belke, Gunther Schnabl and Holger Zemanek, Real Convergence, Capital Flows, and Competitiveness in Central and Eastern Europe, October 2009

2836 Bruno S. Frey, Simon Luechinger and Alois Stutzer, The Life Satisfaction Approach to Environmental Valuation, October 2009

2837 Christoph Böhringer and Knut Einar Rosendahl, Green Serves the Dirtiest: On the Interaction between Black and Green Quotas, October 2009

2838 Katarina Keller, Panu Poutvaara and Andreas Wagener, Does Military Draft Discourage Enrollment in Higher Education? Evidence from OECD Countries, October 2009

2839 Giovanni Cespa and Xavier Vives, Dynamic Trading and Asset Prices: Keynes vs. Hayek, October 2009

2840 Jan Boone and Jan C. van Ours, Why is there a Spike in the Job Finding Rate at Benefit Exhaustion?, October 2009

2841 Andreas Knabe, Steffen Rätzel and Stephan L. Thomsen, Right-Wing Extremism and the Well-Being of Immigrants, October 2009

2842 Andrea Weber and Christine Zulehner, Competition and Gender Prejudice: Are Discriminatory Employers Doomed to Fail?, November 2009

2843 Hadi Salehi Esfahani, Kamiar Mohaddes and M. Hashem Pesaran, Oil Exports and the Iranian Economy, November 2009 
2844 Ruediger Bachmann and Christian Bayer, Firm-Specific Productivity Risk over the Business Cycle: Facts and Aggregate Implications, November 2009

2845 Guglielmo Maria Caporale, Burcu Erdogan and Vladimir Kuzin, Testing for Convergence in Stock Markets: A Non-Linear Factor Approach, November 2009

2846 Michèle Belot and Jan Fidrmuc, Anthropometry of Love - Height and Gender Asymmetries in Interethnic Marriages, November 2009

2847 Volker Nitsch and Nikolaus Wolf, Tear Down this Wall: On the Persistence of Borders in Trade, November 2009

2848 Jan K. Brueckner and Stef Proost, Carve-Outs Under Airline Antitrust Immunity, November 2009

2849 Margarita Katsimi and Vassilis Sarantides, The Impact of Fiscal Policy on Profits, November 2009

2850 Scott Alan Carson, The Relationship between Stature and Insolation: Evidence from Soldiers and Prisoners, November 2009

2851 Horst Raff and Joachim Wagner, Intra-Industry Adjustment to Import Competition: Theory and Application to the German Clothing Industry, November 2009

2852 Erkki Koskela, Impacts of Labor Taxation with Perfectly and Imperfectly Competitive Labor Markets under Flexible Outsourcing, November 2009

2853 Cletus C. Coughlin and Dennis Novy, Is the International Border Effect Larger than the Domestic Border Effect? Evidence from U.S. Trade, November 2009

2854 Johannes Becker and Clemens Fuest, Source versus Residence Based Taxation with International Mergers and Acquisitions, November 2009

2855 Andreas Hoffmann and Gunther Schnabl, A Vicious Cycle of Manias, Crashes and Asymmetric Policy Responses - An Overinvestment View, November 2009

2856 Xavier Vives, Strategic Supply Function Competition with Private Information, November 2009

2857 M. Hashem Pesaran and Paolo Zaffaroni, Optimality and Diversifiability of Mean Variance and Arbitrage Pricing Portfolios, November 2009

2858 Davide Sala, Philipp J.H. Schröder and Erdal Yalcin, Market Access through Bound Tariffs, November 2009

2859 Ben J. Heijdra and Pim Heijnen, Environmental Policy and the Macroeconomy under Shallow-Lake Dynamics, November 2009

2860 Enrico Spolaore, National Borders, Conflict and Peace, November 2009 
2861 Nina Czernich, Oliver Falck, Tobias Kretschmer and Ludger Woessmann, Broadband Infrastructure and Economic Growth, December 2009

2862 Evžen Kočenda and Martin Vojtek, Default Predictors and Credit Scoring Models for Retail Banking, December 2009

2863 Christian Gollier and Martin L. Weitzman, How Should the Distant Future be Discounted when Discount Rates are Uncertain?, December 2009

2864 Tiberiu Dragu and Mattias Polborn, Terrorism Prevention and Electoral Accountability, December 2009

2865 Torfinn Harding and Beata Smarzynska Javorcik, A Touch of Sophistication: FDI and Unit Values of Exports, December 2009

2866 Matthias Dischinger and Nadine Riedel, There's no Place like Home: The Profitability Gap between Headquarters and their Foreign Subsidiaries, December 2009

2867 Andreas Haufler and Frank Stähler, Tax Competition in a Simple Model with Heterogeneous Firms: How Larger Markets Reduce Profit Taxes, December 2009

2868 Steinar Holden, Do Choices Affect Preferences? Some Doubts and New Evidence, December 2009

2869 Alberto Asquer, On the many Ways Europeanization Matters: The Implementation of the Water Reform in Italy (1994-2006), December 2009

2870 Choudhry Tanveer Shehzad and Jakob De Haan, Financial Reform and Banking Crises, December 2009

2871 Annette Alstadsæter and Hans Henrik Sievertsen, The Consumption Value of Higher Education, December 2009

2872 Chris van Klaveren, Bernard van Praag and Henriette Maassen van den Brink, Collective Labor Supply of Native Dutch and Immigrant Households in the Netherlands, December 2009

2873 Burkhard Heer and Alfred Maußner, Computation of Business-Cycle Models with the Generalized Schur Method, December 2009

2874 Carlo Carraro, Enrica De Cian and Massimo Tavoni, Human Capital Formation and Global Warming Mitigation: Evidence from an Integrated Assessment Model, December 2009

2875 André Grimaud, Gilles Lafforgue and Bertrand Magné, Climate Change Mitigation Options and Directed Technical Change: A Decentralized Equilibrium Analysis, December 2009

2876 Angel de la Fuente, A Mixed Splicing Procedure for Economic Time Series, December 2009 
2877 Martin Schlotter, Guido Schwerdt and Ludger Woessmann, Econometric Methods for Causal Evaluation of Education Policies and Practices: A Non-Technical Guide, December 2009

2878 Mathias Dolls, Clemens Fuest and Andreas Peichl, Automatic Stabilizers and Economic Crisis: US vs. Europe, December 2009

2879 Tom Karkinsky and Nadine Riedel, Corporate Taxation and the Choice of Patent Location within Multinational Firms, December 2009

2880 Kai A. Konrad, Florian Morath and Wieland Müller, Taxation and Market Power, December 2009

2881 Marko Koethenbuerger and Michael Stimmelmayr, Corporate Taxation and Corporate Governance, December 2009

2882 Gebhard Kirchgässner, The Lost Popularity Function: Are Unemployment and Inflation no longer Relevant for the Behaviour of Germany Voters?, December 2009

2883 Marianna Belloc and Ugo Pagano, Politics-Business Interaction Paths, December 2009

2884 Wolfgang Buchholz, Richard Cornes and Dirk Rübbelke, Existence and Warr Neutrality for Matching Equilibria in a Public Good Economy: An Aggregative Game Approach, December 2009

2885 Charles A.E. Goodhart, Carolina Osorio and Dimitrios P. Tsomocos, Analysis of Monetary Policy and Financial Stability: A New Paradigm, December 2009

2886 Thomas Aronsson and Erkki Koskela, Outsourcing, Public Input Provision and Policy Cooperation, December 2009

2887 Andreas Ortmann, "The Way in which an Experiment is Conducted is Unbelievably Important": On the Experimentation Practices of Economists and Psychologists, December 2009

2888 Andreas Irmen, Population Aging and the Direction of Technical Change, December 2009

2889 Wolf-Heimo Grieben and Fuat Şener, Labor Unions, Globalization, and Mercantilism, December 2009 